\title{
Openness, Government Size and the Terms of Trade*
}

\author{
Paolo Epifani ${ }^{\dagger}$ \\ Università Bocconi
}

\author{
Gino Gancia ${ }^{\ddagger}$ \\ CREI, UPF and CEPR
}

January 2008

\begin{abstract}
This paper investigates the relationship between trade openness and the size of governments, both theoretically and empirically. We argue that openness can increase the size of governments through two channels: (1) a terms of trade externality, whereby trade lowers the domestic cost of taxation, and (2) the demand for insurance, whereby trade raises risk and public transfers. We provide a unified framework for studying and testing these two mechanisms. Our main theoretical prediction is that the relative strength of the two explanations depends on a key parameter, namely, the elasticity of substitution between domestic and foreign goods. Moreover, while the first mechanism is inefficient from the standpoint of world welfare, the second is instead optimal. In the empirical part of the paper, we provide new evidence on the positive association between openness and government size and we explore its determinants. Consistently with the terms of trade externality channel, we show that the correlation is contingent on a low elasticity of substitution between domestic and foreign goods. Our findings raise warnings that globalization may have led to inefficiently large governments.
\end{abstract}

JEL Classification: F1, H1

Keywords: Openness; Government Size; Terms of Trade Externality; Elasticity of Substitution between Imports and Exports.

${ }^{*}$ We are very grateful to Jaume Ventura for many insightful discussions. We also thank Daron Acemoglu, Pol Antras, Roland Benabou, Alessandra Bonfiglioli, Giovanni Bruno, Carlo Devillanova, Jordi Gali', Philippe Martin, Fabrizio Onida, Torsten Persson, Rick van der Ploeg, Dani Rodrik, Michele Ruta, Guido Tabellini, Dieter Urban, Fabrizio Zilibotti and seminar participants at Harvard, MIT, the NBER SI 2006, the CEPR-ESSIM 2006, CREI, UPF, the European University Intitute, Bocconi University, Gutenberg University, Warwick University, Tubingen, Paris 1-Jourdan, the University of Zurich, the Franco Modigliani Workshop in Rome, the third CEPR-RTN conference on Trade Industrialization and Development, the EEA Meetings in Vienna, the SED Meeting in Prague, the IADB conference in Kiel and the CSGR conference on the Future of Global and Regional Governance for comments. All errors are our own. Gino Gancia thanks the Spanish Ministerio de Ciencia y Tecnologia (grant SEC2002-03816), and the RTN grant "Macroeconomic Policy Design for Monetary Unions" for financial support.

${ }^{\dagger}$ CESPRI, Università Commerciale Luigi Bocconi, via Sarfatti 25, 20136, Milano (Italy). E-mail: paolo.epifani@unibocconi.it

${ }^{\ddagger}$ CREI, Universitat Pompeu Fabra and CEPR, Ramon Trias Fargas, 25-27, 08005, Barcelona (Spain). E-mail: gino.gancia@upf.edu 


\section{Introduction}

The link between globalization and the size of governments is a major issue, yet not a fully understood one. According to some authors, integration of markets should reduce the effectiveness of domestic policies and put competitive pressure to reduce government activism. Since a large public sector may cause a loss of international competitiveness (e.g., Alesina and Perotti, 1997), it may lower the demand for exports and employment, and favor the outflow of mobile factors (e.g., Gordon, 1983, Wilson, 1987, Persson and Tabellini, 1992). This suggests that more economic integration will tend to reduce tax rates, possibly leading to smaller governments and a downsizing of the welfare state. Yet, the empirical evidence shows that openness to trade is associated with larger governments. This pattern was first unveiled by Cameron (1978) for 18 OECD countries and extended to a much broader sample in a seminal paper by Rodirk (1998). ${ }^{1}$ The positive association is not limited to the cross section. On average, international trade and public sectors have grown together and a majority of countries that opened their markets have experienced significant increases in public expenditure.

This stylized fact is often viewed as puzzling. The main explanation put forward in the literature is due to Rodrik $(1997,1998)$, who argues that public spending may provide insurance in economies subject to the risk of international markets. If exposure to risk grows with trade openness, so does the demand for public insurance. ${ }^{2}$ According to this view, the growth of governments in the era of globalization should be welcome as the optimal response to the intrinsic riskiness of open markets.

In this paper, we suggest an alternative and less optimistic explanation. Building on insights from models of non-cooperative fiscal policy in open economies, we argue that trading countries tend to have larger governments because they benefit from a terms of trade externality that shifts part of the cost of taxation abroad. Since governments behaving non-cooperatively do not internalize the cost of taxation that trade imposes onto foreigners, they react to market integration by increasing public spending. ${ }^{3}$

\footnotetext{
${ }^{1}$ Other studies investigating specifically the correlation between openness and government size include the UN-World Public Sector Report (2001), Garrett (2001), Islam (2004) and Garen and Trask (2005). Some authors are skeptical about the robustness of this empirical regularity. Notably, Alesina and Wacziarg (1998) argue that it may be spuriously driven by country size, because small countries tend to have large public sectors and be very open. While their point is certainly important, our empirical results in Section 3 suggest that the correlation between government size and openness is robust to the inclusion of country size.

${ }^{2}$ There are different channels through which globalization may increase risk. Rodrik (1997) emphasizes that globalization may raise the elasticity of demand for labor, thereby exacerbating the effect on wages of domestic productivity shocks. Rodrik (1998) argues instead that open countries are more exposed to the terms of trade variability induced by external shocks.

${ }^{3}$ See Persson and Tabellini (1995) for a survey of the literature on fiscal policy in open economies. In particular, van der Ploeg (1987), Turnovsky (1988), Devereux (1991), Andersen et al. (1996) have
} 
Our main purpose is to compare and test these two mechanisms. To this end, we build a stylized model in which both forces are at work. In particular, we study a world economy where benevolent governments set labor taxes unilaterally to finance countryspecific public goods and provide insurance against productivity shocks through transfers. We then show how the size of governments depends on the degree of trade openness and key parameters.

First, in a world of open countries, an expansion of the public sector crowds out exports and leads to a terms of trade improvement that spreads the cost of taxation beyond national borders. This happens irrespective of countries being large or small, provided that they produce goods that are not perfect substitutes. ${ }^{4}$ In particular, the domestic cost of taxation is lower the higher the trade share and the lower the elasticity of substitution between import and export. The intuition for this result is that tax revenue is spent on domestically produced public goods while a fraction of private income is spent on foreign products. It follows that a shift in the composition of local expenditure from the private to public sector raises the relative demand for domestic labor, the more so the higher the share of imports in private consumption. Yet, for this change in local demand to affect domestic prices and wages, the elasticity of substitution between goods produced in different countries has to be less then infinite, or else prices and wages would be entirely determined on world markets. This induced terms of trade improvement is what makes taxation and public spending less costly in open countries producing differentiated goods. ${ }^{5}$

Second, in a world with uncertainty arising from idiosyncratic productivity shocks, the government can use transfers to act as a provider of insurance. In the spirit of Newbery and Stiglitz (1984) and Rodrik (1997), we show that the demand for public insurance and the equilibrium size of transfers may rise with trade openness. The reason is that in a closed

shown that public expenditure shifting demand in favor of domestic goods may bring about a terms of trade improvement leading to overspending. More recently, Corsetti and Pesenti (2001) and Galí and Monacelli (2005) have built important models of international transmission of monetary and fiscal policies in the presence of such terms of trade effects. Yet, all these papers are focused on issues other than the relationship between the size of government and the volume of trade. Most surprisingly, terms of trade externalities have never been used to explain the empirical association between openness and the size of government, nor have they been compared to other possible explanations. The purpose of this paper is precisely to fill this gap.

${ }^{4}$ For example, mobile phones by Nokia are not perceived as identical to those by Motorola, so that a country as small as Finland does not have to take the export price as given. If the price of a Nokia phone partially reflects the high domestic taxes, every unit sold to foreigners provides a subsidy to the Finnish welfare state. Even exporters of commodities need not be price takers: for example, Madagascar, an exporter of vanilla, has market power because Malagasy vanilla is considered of higher quality than that from other countries.

${ }^{5}$ It is important to note that this mechanism, while related to the optimal tariff argument, is conceptually different from it. In setting an optimal tariff, the government tries to increase the terms of trade up to the level that maximizes domestic revenues, just like a monopolist. In the case we study, instead, the government set taxes to finance public consumption and the induced terms of trade improvement always reduces the cost of public spending, irrespective of the level of domestic and foreign prices. 
economy changes in relative prices across sectors provide insurance against productivity shocks, as prices rise when output falls. International competition with producers of close substitutes poses instead a limit to price variability thereby reducing the stabilizing role of prices and increasing the expenditure for transfers. Thus, more openness exposes an economy to higher income risk the larger the elasticity of substitution between imports and exports. Comparing this result with the previous one, we learn that terms of trade movements, and thus the elasticity of substitution between domestic and foreign products, have contrasting effects on the link between globalization and the size of government: on the one hand, they introduce an externality that leads to higher taxation, on the other, they tend to stabilize income in international markets, thus lowering the demand for public insurance in sectors exposed to foreign competition.

The two explanations differ fundamentally in their welfare properties. While the expansion of the public sector for insurance motives can be the optimal reaction to higher risk, the terms of trade externality leads to excessively large governments, as policy makers do not fully internalize the cost of taxation. In the latter case, when all governments raise spending in response to more trade openness, the result is overprovision of public goods and no change in the terms of trade for any country, as policies just offset each other. $^{6}$ Taking this effect into account, we show that the net impact of an increase in trade on world welfare may even become negative, because the gains from trade may fail to compensate the inefficiency arising from excessive public spending.

The opposite welfare implications of the two mechanisms make it particularly important to assess their empirical relevance. This is the goal of the second part of the paper. To set the stage, we show new evidence on the positive association between openness and government size. Using a large dataset comprising up to 143 countries observed over half a century (1950-2000), we document two important empirical facts. First, that the correlation between openness and government size holds strong both across countries and over time. Second, that there is no evidence of a positive association between openness and government transfers for social security and welfare.

Then, we explore the role played by the elasticity of substitution between import and export in the relationship between openness and governments. Identifying this elasticity is a hard task and we therefore rely on two different strategies. The first aims at providing proxies of this elasticity for individual countries building on the idea that countries exporting differentiated goods should face a lower average export demand elasticity. In particular, using data on the structure of commodity trade, we compute two country-level

\footnotetext{
${ }^{6}$ Strictly speaking, this is true in a symmetric equilibrium. When countries are asymmetric, different domestic policies will dampen each other, but the terms of trade will generally move.
} 
measures of export differentiation: one builds on Rauch (1999)'s classification of traded commodities into differentiated and homogeneous products, the other on Broda and Weinstein (2006)'s estimates of the elasticity of substitution across sectors. We then use these measures of export differentiation as inverse proxies for the elasticity of substitution and interact them with openness to see how they affect the relationship between openness and governments. The introduction of the new terms in the estimation equation yields striking results that are robust across specifications and to the inclusion of controls: openness and government size are positively correlated only for countries exporting differentiated products, precisely as implied by the terms of trade motive.

Our second strategy builds on Acemoglu and Ventura (2002) and allows to recover direct estimates of the terms of trade externality across groups of countries. We start by showing that countries growing faster than average experience a deterioration of their terms of trade, this suggesting that countries are not, on average, price takers. In particular, our estimates are consistent with an average elasticity of substitution between import and export lower than 3. We also show that, as in our model, government expenditure crowds out private production, which in turn leads to a terms of trade improvement, and that public expenditure has no direct effect on the terms of trade. More importantly, we show that the terms of trade externality is much bigger (implying an elasticity of substitution around 1.5) for the group of countries exhibiting a relatively stronger correlation between openness and government size.

The finding that terms of trade considerations are a driving force behind the growth of the public sector may appear surprising at first. Nevertheless, it becomes much more plausible once we recognize that the logic behind it is the widespread Keynesian view that public expenditure can be used to sustain demand for domestic products and labor. Crucial for this is the assumption that public expenditure is home-biased. On this respect, the evidence leaves no doubts. For example, in a sample of 14 (developed and developing) countries with available data, the average import share in government consumption is a slim 1\%, while the economy-wide import share is around $47 \%$ (see the Appendix for more details on these numbers). It follows naturally that the demand switching effect of public spending is stronger the higher the degree of openness of the private sector and that big changes in openness can affect substantially government incentives to boost employment through fiscal policy. ${ }^{7}$ In fact, our model suggests the effect of openness on

\footnotetext{
${ }^{7}$ A recent example of this logic is the following statement, made by a PIMCO spokesman, on how to give a stimulus to the US economy: "Consumers will just buy more Chinese goods with stimulus package money, more of the same. What is needed is public investment to fill demand void of private sector". This is the mechanism we stress in action: as the import share increases, sustaining demand via public spending is preferred to a tax cut. A government not using expansionary public spending would instead suffer an
} 
public spending to be quantitatively large: reasonable calibrations show that the observed increase of average openness between 1950 and 2000 (42.5 percentage points) can explain between $16 \%$ to $45 \%$ of the overall average increase in public spending during the same period (from $10.2 \%$ of GDP to $22 \%$ ).

Finally, this paper is part of a growing literature demonstrating the empirical relevance of terms of trade considerations in many contexts. For example, terms of trade movements create sizeable growth externalities across countries (e.g., Acemoglu Ventura, 2002, Vilarrubia, 2006); they lead to incomplete pass-through of exchange rate shocks (see Goldberg and Knetter, 1997, for a survey) and of tariffs (e.g., Feenstra, 2004, pp. 235-240); they affect the structure of protection across goods and countries (Limao, 2006, and Broda, Limao and Weinstein, 2006); they are a significant factor in trade negotiations (Bagwell and Staiger, 2006); they appear to be an indispensable ingredient in explaining co-movements in new open-economy business cycle models, where the assumption of a low elasticity of substitution between domestic and foreign goods is becoming the norm. Within this vast literature, particularly interesting for our purpose is the empirical finding in Monacelli and Perotti (2008) that a rise in government spending generates a significant appreciation of the terms of trade.

The paper is organized as follows. Section 2 illustrates the model, Section 3 brings it to the data, and Section 4 concludes.

\section{A Simple Model of Trade and Governments}

We construct a simple static model of a world economy with a large number $N$ of identical countries and a continuum $[0,1]$ of industries. Each industry produces differentiated goods and countries are specialized in different varieties. Consumers enjoy utility from the consumption of differentiated goods and a country-specific public good. Governments of each country have two functions: to produce public goods (e.g., education, defense, civil infrastructures) financed through taxation and to provide public insurance against idiosyncratic shocks (e.g., social security and welfare) through transfers. Governments set policies unilaterally so as to maximize utility of domestic citizens. Trade takes place because consumers like variety. However, we consider a situation of imperfect market integration where trade may not be allowed in all industries. We then use the model to explore how the degree of trade openness can affect the expenditure on public goods and transfers. ${ }^{8}$

adverse movement in relative wages and be forced to implement policies in support of demand.

${ }^{8}$ We purposefully distinguish between the two functions of the government, as a provider of insurance and public goods, to preserve the highest transparency in studying the determinants of each component 


\subsection{The World Economy}

Consumers in all countries are risk-averse and share the same preferences represented by the following expected utility function:

$$
E U=E \frac{C^{1-\rho}}{1-\rho}, \quad \rho>0
$$

where $E$ is the expectation operator, $\rho$ is the coefficient of relative risk-aversion and

$$
C=\left(\exp \int_{0}^{1} \log Y_{j} d j\right)^{\eta} G^{1-\eta}, \eta \in(0,1)
$$

where $Y_{j}$ is the subutility derived from consumption of differentiated goods produced in sector $j \in[0,1]$ and $G$ is the consumption of a country-specific public good. The parameter $\eta$ captures consumer preferences for private versus public goods.

The world we describe contains a large number of small countries, indexed by $i \in$ $\{1, \ldots, N\}$, each specialized in the production of a single variety $i$ in every sector $j .{ }^{9}$ Full specialization follows from the Armington assumption that goods are differentiated by the country of origin. ${ }^{10}$ Preferences for differentiated goods in each sector $j$ are represented by a CES subutility function:

$$
Y_{j}=N^{\nu+1}\left(\frac{1}{N} \sum_{i \in N} y_{j, i}^{\frac{\sigma-1}{\sigma}}\right)^{\frac{\sigma}{\sigma-1}}, \sigma>1, \nu \geq 0,
$$

where $y_{j, i}$ is consumption of the variety produced by country $i$ in sector $j$ and $\sigma>1$ is the elasticity of substitution between varieties produced in different countries. ${ }^{11}$ Equation (3) is a generalization, introduced by Benassy (1998), of well-known Dixit-Stiglitz preferences. Its special property is that the term $N^{\nu-1 /(\sigma-1)}$ allows us to disentangle the elasticity of substitution between product varieties from the preference for variety. From (3), greater variety is associated with higher utility whenever $\nu>0$. To see this, suppose each (identical) country produces the same amount $y$, so that consumption of a variety in any given country is $y / N$. Then, the sub-utility $Y_{j}$ becomes $N^{\nu} y$, which is increasing in $N$

of public expenditure. In reality, of course, such a distinction would be more blurred.

${ }^{9}$ The assumption that countries are small makes the game played by governments non-strategic, in the sense that governments do not react to any change of policy in any (small) foreign countries. This assumption is for convenience and is not essential for the results.

${ }^{10}$ The fact that specialization is here assumed is just a simplification as it would be possible to derive it as the equilibrium outcome of more general models.

${ }^{11}$ The assumption $\sigma>1$ rules out immiserizing growth. For the main results, a milder restriction is sufficient. With a slight abuse of notation, we refer to $y_{j, i}$ as both consumption and production of a given variety. In aggregate, of course, the two will be identical. In the text, we always specify whether we mean consumption or production. 
if $\nu>0$. The standard Dixit-Stiglitz preferences are a special case of $(3)$ for $\nu=(\sigma-1)^{-1}$. We follow the more general formulation because distinguishing between the elasticity of substitution and the preference for variety can be important for welfare analysis. ${ }^{12}$

We model imperfect economic integration between countries by assuming that in some sectors goods can be freely traded in international markets, while in others trade costs are prohibitive. Accordingly, the unit measure of sectors is partitioned into two subsets of traded and nontraded industries. Sectors are ordered such that those with an index $j \leq \tau \in[0,1]$ are subject to negligible trade costs and the others, with an index $j>\tau$, face prohibitive trade costs. We refer to "globalization" as an increase in the measure $\tau$ of traded goods, i.e., the fall in trade costs (from prohibitive to zero) in some sectors. ${ }^{13}$ An important advantage of this approach is that it offers a very natural measure of trade openness with a simple empirical counterpart. In particular, note that the utility function (2) implies that expenditure is divided evenly across sectors. Together with the assumption that each country is small and thus exports its entire domestic production of the traded goods, this implies that $\tau$ is the share of imports (or exports, given balanced trade) in private spending.

In any traded sector $(j \leq \tau)$, maximization of (3) subject to a budget constraint yields CES demand functions with a price-elasticity of $\sigma$ :

$$
\frac{p_{j, i}}{Q_{j}}=N^{\nu-(\nu+1) / \sigma}\left(\frac{Y_{j}}{y_{j, i}}\right)^{1 / \sigma}
$$

where

$$
Q_{j} \equiv N^{-\nu}\left(\frac{1}{N} \sum_{i \in N} p_{j, i}^{1-\sigma}\right)^{\frac{1}{1-\sigma}}
$$

can be interpreted as the ideal price index in sector $j$, i.e., the minimum cost of one unit of $Y_{j}$. Given that each country exports all its production and imports all its consumption of traded goods, ${ }^{14}$ equation (4) gives the terms of trade of country $i$ in sector $j$ : the price of export relative to the price of the imported basket. Note that a fall (rise) of domestic production improves (worsens) the country's terms of trade. This happens despite each country being small, because countries are specialized in the production of goods that

\footnotetext{
${ }^{12}$ None of our main results requires $\nu \neq(\sigma-1)^{-1}$.

${ }^{13}$ Although this is a stylized description of reality, it accords well with the observation that there are areas of economic activity where the degree of market integration is low. There is also growing evidence that trade between countries has increased more along the extensive margin (more goods are traded today than in the past) than along the intensive margin (higher volumes of trade in the same goods). As shown, for instance, by Broda and Weinstein (2006), the number of product varieties imported by the US over the last three decades has increased by a factor of four.

${ }^{14}$ This is true as $N$ goes to infinity. It is taken as an approximation when the number of countries is large.
} 
are imperfect substitutes. In any nontraded sectors $(j>\tau)$, instead, each country $i$ only consumes its own domestic output, $y_{j, i}$.

\subsection{Country Equilibrium}

Consider now a single country. For simplicity, we focus on a symmetric case in which all countries share the same parameters. We remove the index $i$ with the understanding that, unless otherwise stated, all variables now refer to a single country. Labor is the only factor of production and is employed by competitive firms to produce both private and public goods. Labor productivity in any sector $j$ is assumed to be the realization of a random variable $\pi$ that takes value $\bar{\pi}=1+\epsilon$ (with $0 \leq \epsilon<1$ ) in good states and $\underline{\pi}=1-\epsilon$ in bad states. Good and bad states are equally likely and each industry $j$ in each country $i$ is subject to independent realizations of $\pi$. That is, shocks are uncorrelated across sectors and countries. ${ }^{15}$ Moreover, we assume that workers must choose the sector of employment before the realization of the productivity shock and cannot move everafter. We take this as a fair representation of a short-run equilibrium in which labor mobility is not perfect. If the economy repeats itself and shocks are uncorrelated over time, this equilibrium will also prevail in the long-run, provided that frictions to labor mobility prevent workers from exploiting short-run gains from positive temporary shocks. ${ }^{16}$ Given that markets are competitive, workers are paid the value of their marginal product:

$$
w_{j}=p_{j} \pi_{j}
$$

Under complete markets, workers would be able to insure the idiosyncratic productivity shock. However, in the following we rule out private insurance markets, or else there would be no role for public insurance, but we allow the government to stabilize income by way of transfers. Since workers are risk-averse, providing full insurance is the optimal strategy for a benevolent government that seeks to maximize utility of its citizens. We assume that government transfers are such that all workers in sector $j$ have an ex-post income equal to the expected wage in the sector, $E\left(w_{j}\right)$. Anticipating this, workers allocate themselves across sectors so as to maximize the expected wage, as if they where risk-neutral. Given that sectors are ex-ante identical and that expenditure is equally allocated between them,

\footnotetext{
${ }^{15}$ We assume that the number of countries $N$ is large enough so that the law of large numbers applies. This means that there is no aggregate uncertainty.

${ }^{16}$ Labor mobility across sectors may be limited, for example, by sector-specific human capital and labor market frictions. If the labor immobility assumption is relaxed, then workers would not be exposed to any income risk. This would break the demand for insurance mechanism, though not the terms of trade argument. Yet, risk and insurance motives would be restored as long as there is any sector-specific factor, as for example in Grossman and Helpman (1994).
} 
workers spread evenly across sectors and all have the same ex-post income $w$.

In the public sector, we assume that one unit of labor can be employed to produce one unit of the public good, $G$. The public sector is not subject to uncertainty, because it is intended as a large set of activities over which idiosyncratic shocks are averaged out. ${ }^{17}$ To finance public production, the government sets a tax $g$ on labor income, so that the total tax revenue is $g w L$, where $L$ is the country labor force and $w$ the average wage rate. ${ }^{18}$ Without uncertainty, the public sector has to pay the average wage and thus provision of the public good can be found as:

$$
G=g L
$$

which is also employment in the public sector. Given that $g w L$ is total spending on public goods while $w L$ is the country's GDP, $g$ is also the share of government production in GDP.

Imposing labor market clearing, $\int_{0}^{1} L_{j} d j+g L=L$, and recalling that $L_{j}$ is constant across sectors, we can solve for employment and production in any sector $j \in[0,1]$ :

$$
\begin{aligned}
L_{j} & =(1-g) L, \\
y_{j} & =\pi_{j}(1-g) L .
\end{aligned}
$$

To study the decision problem faced by the government, we first need to solve for the utility of the representative agent at a given level of taxation. As a preliminary step, it will prove useful to define consumption of any single nontraded good and traded basket in a world without uncertainty (i.e., for $\epsilon=0$ ). In this case, country consumption of nontraded goods is equalized across industries and given by:

$$
Y_{n} \equiv(1-g) L
$$

Note that an increase in government production $g$ lowers $Y_{n}$ one to one because it shifts labor out of the private sector. Consumption of any traded basket $Y_{j}$ can instead be found dividing the expenditure allocated to a sector, $w L(1-g)$, by the ideal price index:

$$
Y_{\tau} \equiv \frac{w L(1-g)}{Q}=[(1-g) L]^{\frac{\sigma-1}{\sigma}} N^{\nu-(\nu+1) / \sigma}\left(Y_{w}\right)^{\frac{1}{\sigma}}
$$

\footnotetext{
${ }^{17}$ See also Galí (1994) and Fátas and Mihov (2001) on this point. They find evidence of a robust negative correlation between various measures of government size and per capita GDP volatility in OECD countries.

${ }^{18}$ The form of taxation is not crucial for the results, because the key assumption is not on how the government raises tax revenues, but rather on how these are spent. When taxes are spent on domestically produced public goods, an increase in taxation shifts demand towards domestic goods and thus raises wages. Distortionary taxation would reinforce the result, as open countries do not fully internalize the distortion they impose on the world economy.
} 
where we have used (6), (9), (4) and $Y_{w}$ is world consumption of any traded basket when $\epsilon=0$. Equation (11) shows that an increase in government production $g$ does not reduce traded consumption, $Y_{\tau}$, one to one as long as it brings about a terms of trade improvement: by means of (4), the fall in domestic production $L(1-g)$ is partially compensated by a rise in $p / Q$ so that income falls less than proportionally in traded sectors.

Finally, aggregating over industries and following the conventional assumption that the public good is non-rival, the utility function (2) of the representative agent in the presence of uncertainty reduces to:

$$
C=\left[\frac{\left(\Omega_{n} Y_{n}\right)^{1-\tau}\left(\Omega_{\tau} Y_{\tau}\right)^{\tau}}{L}\right]^{\eta} G^{1-\eta}
$$

where the terms $\Omega_{n} \equiv\left(1-\epsilon^{2}\right)^{1 / 2} \leq 1$ and $\Omega_{\tau} \equiv\left[\frac{1}{2}(1+\epsilon)^{\frac{\sigma-1}{\sigma}}+\frac{1}{2}(1-\epsilon)^{\frac{\sigma-1}{\sigma}}\right]^{\frac{\sigma}{\sigma-1}} \leq 1$ quantify the utility cost of fluctuations in consumption across sectors due to productivity shocks and are inverse measures of consumption risk, for a given income. ${ }^{19}$ Note that $\Omega_{n}=\Omega_{\tau}=1$ in case of no uncertainty (i.e., for $\epsilon=0$ ), while both $\Omega_{n}$ and $\Omega_{\tau}$ are decreasing in $\epsilon$. That is, utility falls with the variance of shocks $\left(\epsilon^{2}\right)$ because consumers would like to smooth consumption across sectors. Moreover, $\Omega_{n} \leq \Omega_{\tau}$ because in traded industries the fall in consumption of varieties hit by negative shocks is partially compensated by the rise in consumption of varieties subject to positive shocks, the more so the higher is the degree of substitutability across varieties.

\subsection{Openness and Public Goods}

Government spending on public goods $(g)$ is chosen in each country so as to maximize the utility of its representative citizen, taking world prices, $Q$, and production, $Y_{w}$, as given. Substituting (7), (10) and (11) into (12), and noting that $U(1)$ is an increasing function of $C(12)$, the objective function of the government becomes:

$$
\underset{g}{\operatorname{Max}} C=(1-g)^{\eta(1-\tau / \sigma)}\left(\Omega_{n}\right)^{(1-\tau) \eta}\left[\Omega_{\tau} N^{\nu-(\nu+1) / \sigma}\left(\frac{Y_{w}}{L}\right)^{1 / \sigma}\right]^{\tau \eta}(g L)^{1-\eta},
$$

\footnotetext{
${ }^{19}$ To find (12), note that consumption of a nontraded good is $\pi_{j} L_{j}$ while consumption of a traded basket is $\left(\int_{0}^{\tau} w_{z} L_{z} d z\right) /\left(\tau Q_{j}\right)$, where $w_{z}=Q_{z}\left(\pi_{z}\right)^{\frac{\sigma-1}{\sigma}} N^{\nu-\frac{\nu+1}{\sigma}}\left(Y_{z} / L_{z}\right)^{\frac{1}{\sigma}}$. Noting that $Q_{z}=Q_{j}, \forall z, j \in[0, \tau]$ and $Y_{z}=\Omega_{\tau} Y_{w}, \forall z \in[0, \tau]$, and substituting into (2) yields (12), once definitions (10) and (11) are used.
} 
which leads to the first order condition: ${ }^{20}$

$$
\frac{\eta}{1-g}\left(1-\frac{\tau}{\sigma}\right)=\frac{1-\eta}{g}
$$

The left hand side of (14) is the marginal cost of taxation. It can be interpreted as the marginal utility of private consumption multiplied by the fall in private consumption due to an increase in taxation. The volume of trade, $\tau$, lowers the cost of taxation because, as just seen, income in traded sectors falls less than proportionally with $g$. The right hand side is instead the marginal value of public production, which is proportional to the preference for the public good, $1-\eta$, and declines with $g$ because of decreasing marginal utility. Solving (14) yields:

$$
g=\frac{1-\eta}{1-\eta \tau / \sigma}
$$

Not surprisingly, it is easy to see that $g$ is higher the stronger the preference for the public good, $(1-\eta) .{ }^{21}$ More interestingly, so long as $\sigma$ is finite, the size of the public sector grows with openness. By now, the intuition for this result should be clear and can be summarized saying that trade lowers the domestic cost of taxation because of a terms of trade externality. Clearly, this depends on the possibility for a country to affect its terms of trade, as can be seen from the sign of the cross derivative:

$$
\frac{\partial^{2} g}{\partial \tau \partial \sigma}<0
$$

Thus, the effect of trade on the public sector is stronger the lower the elasticity of substitution between goods, because a lower elasticity of substitution implies that prices (the terms of trade) react more. Moreover, (15) implies that $g$ increases when $\sigma$ falls as long as there is some trade, $\tau>0$. That is, more product differentiation increases the size of the public sector in open economy. ${ }^{22}$

How large is the effect of changes in $\tau$ on $g$ ? Is it of the same order of magnitude as the empirical correlation between openness and government size? By choosing parameter values, we can use equation (15) to answer these questions. In so doing, however, we first need to recognize the difference between $\tau$ and the openness measure typically used in the empirical literature. Recall that $\tau$ is the import (or export) share in private spending.

\footnotetext{
${ }^{20} \sigma>\tau$ guarantees that the second order condition is satisfied.

${ }^{21}$ This is guaranteed as long as $\sigma>\tau$, also implying $g<1$.

${ }^{22}$ Per capita government spending is instead independent of country size, $L$. This is a special implication of Cobb-Douglas preferences, as discussed in Alesina and Wacziarg (1998). It is also worth noting that if labor supply $L$ was endogenous, the terms of trade externality could help explain why governments of more open European countries are more willing to restrict working hours compared to the US. We are grateful to Philippe Martin for suggesting this.
} 
The most common openness measure, that we label $O$, is instead defined as import plus export over total GDP. The two measures are linked by the following relationship: $\tau=$ $O /[2(1-g)]$. Substituting this into $(15)$ and deriving with respect to $O$ yields:

$$
\frac{\partial g}{\partial O}=\frac{\eta g(1-g)}{2 \sigma(1-g)^{2}-\eta O}
$$

Provided that $O$ is not excessively large, this derivative is positive and decreasing in $\sigma .^{23}$ The crucial parameter to quantify $\partial g / \partial O$ is the elasticity of substitution between varieties, for which we take two benchmark values: $\sigma=1.5$ and $\sigma=3$. This interval is consistent with our own estimates reported in Section 3, as well as those found in other studies, such as Acemoglu and Ventura (2002) and Broda and Weinstein (2006). Next, we set $O=0.86$, equal to the cross-country average over the period 1995-2000, and choose $\eta$ so as to match the average government size of 0.21 in (15). This delivers $\eta=0.85$ for $\sigma=1.5$ and $\eta=0.82$ for $\sigma=3$. Under this parametrization, the derivative $\partial g / \partial O$ varies from 0.044 to 0.123 , an interval that is remarkably close to the empirical estimates reported in Section 3, ranging from 0.054 to 0.15 .

\subsubsection{Robustness}

Although our model is special in many respects, the result that open countries do not fully internalize the cost of domestic taxation is a fairly general one. In fact, it does not depend on many of the simplifying assumptions we used. First, as shown in the Appendix, equation (15) can be generalized by removing the symmetry imposed across countries. This is important because, in reality, countries have different preferences for private versus public goods, different degrees of trade openness, and export goods with widely different characteristics. Introducing asymmetries in all the key parameters will allow us to fully exploit the cross-country variation in the data when testing equation (15) in section 3.

Second, the result is robust to alternative descriptions of the globalization process. Although introducing trade barriers of a different nature may require modifying some aspects of our model, it is unlikely to affect the main result. The reason is that, irrespective of the nature of trade barriers, the value of a terms of trade improvement is necessarily proportional to the volume of trade. Thus, the rise in domestic prices following an increase in taxation is more beneficial for countries relatively more open to trade. ${ }^{24}$

\footnotetext{
${ }^{23}$ More precisely, $\partial g / \partial O$ is positive under the mild restriction $\tau<\sigma(1-\sqrt{1-\eta}) / \eta$.

${ }^{24}$ The feature of our model that the entire domestic production in traded sectors is exported is not crucial. Clearly, a home bias in private consumption at the sector level would tend to weaken the terms of trade externality. Nevertheless, the value of terms of trade improvements would still be proportional to the volume of trade, precisely as in the model.
} 
Third, the result is reminiscent of the optimal tariff argument, whereby a small import tariff or export tax can be welfare enhancing when they bring about a terms of trade improvement. Indeed, our model builds on the same assumption that domestic policies can affect the terms of trade and suggests that even the most basic form of taxation is likely to have such terms of trade effects. However, our result is more general than the optimal tariff argument. In fact, while trade policy is by now restricted in most countries by international trade agreements, income taxes are still viewed as an issue of national sovereignty. More important, our result is independent from the optimal tariff argument: as shown in the Appendix, equation (15) holds unaffected even when the government is optimally setting an export tax or an import tariff. It follows as a corollary that our analysis remains valid if firms have market power, not just countries.

Fourth, the Armington assumption according to which varieties are differentiated by the country of origin simplifies the analysis enormously, by making the pattern of specialization exogenous. Yet, it is not strictly required for the result to hold: the only crucial assumption is that countries be able to affect their terms of trade. This possibility is captured in a parsimonious way by the parameter $\sigma$ in our model. Whether the case of a finite $\sigma$ (for some or all countries) is realistic or not is an empirical question that we address later in the paper. We also want to stress that the terms of trade externality is a general feature of most trade models, and not a specific property of our approach.

Fifth, the assumption of no international labor mobility can be relaxed without overturning the result. On the contrary, we show in the Appendix that labor mobility may even reinforce it. The intuition is as follows. If workers migrate in response to an increase in domestic taxes, this may put a downward pressure on the size of government, as in the literature on tax competition. At the same time, however, the terms of trade now improve more after a rise in $g$ : not only because labor is shifted out of the private sector producing tradeables, but also because the domestic labor force falls. For this reason, the link between $g$ and $\tau$ may actually become stronger. ${ }^{25}$ Frictions to labor mobility across sectors are also immaterial for the terms of trade argument.

Finally, an important limit of our analysis is the lack of politico-economic aspects, in that $g$ is simply chosen by a benevolent government, while in reality the interests of policy makers may not coincide with those of citizens. ${ }^{26}$ In general, the incentive to increase taxation as trade expands would hold so long as maximizing domestic income is among

\footnotetext{
${ }^{25}$ Capital mobility can also make an increase in taxation more costly, due to capital outflows, and thus reduce the size of government. In any event, the effect of international factor mobility is conceptually different from that of trade openness, which is the focus of the paper, because it does not depend on trade in goods, but rather on other aspects of globalization.

${ }^{26}$ See Persson and Tabellini (2000) for an extensive treatment of political economics.
} 
the objectives of politicians. This is often the case in probabilistic voting models (such as Lindbeck and Weibull, 1993) as well as lobbying models (such as Grossman and Helpman, 1994) and may be true in non-democratic political systems too. If part of the tax revenue is used in a socially wasteful way to the private benefit of those who are in power, the terms of trade externality could lower the perceived domestic social cost of this misuse of public resources. Trade can thus promote inefficient policies, for politicians may not fully internalize their costs. Adding different types of agents (e.g., workers and capital owners) with conflicting interests and a voting mechanism to determine the policy outcome goes beyond the scope of this paper and is left for future work. ${ }^{27}$

\subsection{Openness and Public Insurance}

We now consider the other component of the size of government, the amount of redistribution through transfers required to insurance workers from idiosyncratic productivity shocks, and study how it varies with openness. In this setting, openness affects aggregate demand for insurance because risk is borne by workers in traded and nontraded sectors in a very different way. To see this, note that price movements tend to offset fluctuations in productivity: prices rise whenever output falls and thus low productivity in bad times is partially compensated. Given our assumptions, compensation is full in nontraded sectors because demand for nontraded goods has a unitary price elasticity so that no transfer is needed to stabilize income. This can be seen by computing the equilibrium wage offered in a nontraded sector after the realization of the productivity shock:

$$
w_{j}=\frac{w(1-g) L}{L_{j}}=w, \quad j>\tau,
$$

where $w$ is the average wage and $w(1-g) L$ is after-tax income allocated to the consumption of good $j$. The latter equality follows from (8). As the model has no aggregate uncertainty, the variance of wages in nontraded industries is zero.

This is not the case in the traded sectors where there is foreign competition. While the share of world income allocated to a given traded sector is constant due to Cobb-Douglas preferences, its distribution across countries depends on productivity because the elasticity of substitution vis-a-vis foreign varieties, $\sigma$, is higher than one, so that the relative price of domestic varieties does not react enough to provide full insurance. Using (9) and (4),

\footnotetext{
${ }^{27}$ Another interesting set of issues would arise if the short-run elasticity of substitution is lower than in the long-run, e.g., because of habit formation in demand. The government could then increase taxes in the short-run, but be forced to eventually reduce them in the long-run. Persistence in public expenditure would generate additional interesting dynamics that cannot be analyzed in our simple static setup. See, for example, Hassler et al. (2003) for a dynamic politico-economic theory of governments.
} 
equilibrium wage in a traded sector (before transfers), $w_{j}=p_{j} y_{j} / L_{j}$, and its variance can be found as:

$$
\begin{aligned}
w_{j} & =Q_{j}\left(\pi_{j}\right)^{\frac{\sigma-1}{\sigma}} N^{\nu-\frac{\nu+1}{\sigma}}\left(\frac{Y_{j}}{L_{j}}\right)^{\frac{1}{\sigma}}, j \leq \tau, \\
V A R\left(\log w_{j}\right) & =\left(1-\frac{1}{\sigma}\right)^{2} V A R(\log \pi), \quad j \leq \tau,
\end{aligned}
$$

where we have used the fact that, by the law of large numbers, $\operatorname{VAR}\left(Y_{j}\right)=V A R\left(Q_{j}\right)=0$. Income in traded sectors fluctuates more with productivity the higher is $\sigma$, as foreign competition with producers of close substitutes removes the stabilizing role of prices. Thus, our simple framework captures well the argument that trade, by exposing sectors to foreign competition, makes the derived demand for labor more elastic, implying that shocks to productivity result in much greater earnings volatility. ${ }^{28}$

To study the effect of trade on the size of government through the demand for public insurance, we define public spending on insurance $T$ as the total transfer needed to stabilize wages as a share of private GDP. This can be computed as the expected transfer per sector producing traded goods, integrated over the measure of traded sectors and divided by the value of private production:

$$
T=\int_{0}^{\tau} \frac{\left|w_{j}-w\right|}{2 w} d j
$$

Using (17) and $\int_{\tau}^{1} w_{j} d j=\frac{\tau}{1-\tau} \int_{0}^{\tau} w_{j} d j$ yields:

$$
T=\frac{\tau}{2} \cdot \frac{(\bar{\pi} / \underline{\pi})^{\frac{\sigma-1}{\sigma}}-1}{(\bar{\pi} / \underline{\pi})^{\frac{\sigma-1}{\sigma}}+1} .
$$

Total transfers grow with trade openness, $\tau$, the elasticity $\sigma$ and the variance of productivity $\pi{ }^{29}$ As $\sigma \rightarrow 1$ the need for insurance disappears and $T \rightarrow 0$. Thus, the lower the elasticity of substitution between import and export, the lower the need for a riskmitigating role of the public sector in open countries.

\subsubsection{Robustness}

The case of idiosyncratic productivity shocks is both plausible and simple, and this is why we focused on it. Yet, we would like to know what happens with shocks of different types. We now argue that introducing aggregate (rather than idiosyncratic) uncertainty

\footnotetext{
${ }^{28}$ See Rodrik (1997), Chapter 2, for a more extensive discussion of this argument and some empirical evidence. A similar point is made in Newbery and Stiglitz (1984).

${ }^{29}$ It follows immediately that transfers over total GDP (as opposed to private GDP) are also a positive function of the trade share in total GDP.
} 
and demand (rather than supply) shocks is unlikely to change the main conclusion of this section: that the need for insurance falls as the elasticity of substitution between domestic and foreign goods declines. To show this, we briefly discuss how changing the type of shock affects the relationship between trade and risk.

First, assume that $\pi$ is an aggregate, country-specific, productivity shock. That is, all sectors in country $i$ receive the same realization $\pi_{i}$. In autarky, a country would have no mean to insure against such risk. ${ }^{30}$ For an open economy, terms of trade movements do provide some insurance, as it is shown in (17). Rather than amplifying risk, in this case trade dampens wage fluctuations; however, just as we saw before, terms of trade changes provide better insurance when $\sigma$ is low.

Consider now preference (demand) shocks across varieties produced in different countries. These are external shocks, like shifts in world demand in favor (or against) the variety produced by a given sector in a country. Shocks of this sort can be introduced directly into preferences for differentiated varieties:

$$
Y_{j}=N^{\nu+1}\left[\frac{1}{N} \sum_{i \in N}\left(\pi_{j, i}\right)\left(y_{j, i}\right)^{\frac{\sigma-1}{\sigma}}\right]^{\frac{\sigma}{\sigma-1}} .
$$

Note that nontraded sectors are, by construction, insulated from these shocks. On the contrary, deriving demand from (20) it can be shown that

$$
V A R\left(\log w_{j}\right)=V A R(\log \pi), \quad j \leq \tau .
$$

With global shifts in the demand curve, the elasticity of substitution across varieties plays no role in determining a country's exposure to risk. If these shocks are uncorrelated across sectors, workers can be fully insured through transfers. If instead all sectors in a country are hit by the same demand shocks, then full insurance cannot be achieved.

Comparing these cases, we conclude that, regardless of the source of uncertainty, the demand for insurance is (weakly) increasing in the elasticity of substitution between domestic and foreign goods. ${ }^{31}$ Moreover, in a general situation where shocks of all kinds are present, trade will increase risk provided that $\sigma$ is sufficiently high.

An alternative view could be that trade increases aggregate uncertainty by fostering specialization, thereby making the economy more exposed to sectoral shocks. Although this case is not explicitly contemplated in our model, we can think of it as a situation where trade turns idiosyncratic shocks into aggregate shocks to private production (for example,

\footnotetext{
${ }^{30}$ Though it could reduce workers exposure to risk by expanding the "safe" public sector.

${ }^{31}$ Cole and Obstfeld (1991) also support this view.
} 
by shutting down some sectors). Transfers would provide full insurance in autarky, but not with trade, for aggregate uncertainty cannot be diversified. Openness could then lead to an expansion of the safe public sector $G$, as a response to the higher risk exposure of the economy. Even in this case, though, the effect of shocks would be alleviated by price variability so that the demand for insurance would increase more with trade when $\sigma$ is high, just as above. It is also worth emphasizing that, in a world where lump sum transfers are not available, policy makers could increase public employment to reduce the overall exposure to risk, provided that the public sector is safer than the rest of the economy. ${ }^{32}$

\subsection{Welfare}

We now confront the solution to the government problem with the world optimum. Given that redistribution is costless and substitutes for missing insurance markets, it is easy to prove that the increase in transfers due to higher openness is globally efficient. However, the level of taxation chosen unilaterally is not, because governments do not consider the cost of taxation that trade shifts onto foreigners. A world social planner, instead, would internalize the cost of public spending for the world economy. To capture this in our symmetric set up, it suffices to modify the objective function of the government so as to take into account that the equilibrium $g$ will be identical across countries and will thus affect world output. Substituting $Y_{w}=N^{\nu+1}(1-g) L$ into (13) and rearranging yields:

$$
\underset{g}{\operatorname{Max}} C=\left[N^{\nu \tau}\left(\Omega_{n}\right)^{(1-\tau)}\left(\Omega_{\tau}\right)^{\tau}(1-g)\right]^{\eta}(g L)^{1-\eta} .
$$

From the first order condition, it is easy to verify that world welfare is maximized when each country sets the size of the public sector equal to:

$$
g=1-\eta
$$

which is the level chosen in autarky. It follows immediately that, as market integration $(\tau)$ increases, governments behaving non-cooperatively move further away from the globally efficient solution. The reason is that, in the presence of specialization and trade, rising taxes is a beggar-thy-neighbor policy at the expenses of foreign countries and the incentive to use such a policy is higher the larger the trade share.

When all countries set $g$ uncooperatively, welfare may even decline with globalization

\footnotetext{
${ }^{32}$ In our model, we make a sharp distinction between transfers and public employment in order to isolate theoretically the insurance and the cost-shifting motives for increasing government size with openness. In reality, public production is also used for insurance purposes. This channel is explicitly discussed in the literature on the Scandinavian model, where openness is combined with a large welfare system. See, for example, Andersen (2004, 2008).
} 
(an increase in $\tau$ ) because of the inefficient equilibrium response of governments. The reason is a prisoner's dilemma type of problem: as $\tau$ increases, each individual government has an incentive to raise taxation, tough in a symmetric equilibrium no country benefits from any terms of trade improvement, as different policies just offset each others. Yet all consumers loose due to the underprovision of private goods. Then, despite all countries making the individually optimal decision, welfare may decline. In particular, an increase in $\tau$ may be welfare reducing if the inefficiency from excessive public spending it induces outweighs the gains from trade, given by the value of consuming foreign varieties. Thus, welfare losses from globalization will be unlikely when the gains from trade are big, i.e., when there is a large number of countries $N$, a strong preference for variety $\nu$ and a high substitutability across varieties $\sigma$ so that consumption risk is lower in traded sectors (i.e., $\Omega_{\tau}>\Omega_{n}$ ). To see this, take equation (21) and note that, holding the tax rate constant, utility is increasing in trade $(\tau)$ whenever $N>1, \nu>0$ and/or $\Omega_{\tau}>\Omega_{n}$. Moreover, given that public spending on public goods converges to the globally optimal level when the elasticity of substitution increases, the inefficiency from trade is lower when $\sigma$ is high. Formally, substituting $g$ from (15) into (21), the condition for trade to be welfare-improving can be derived as:

$$
\nu \log N+\log \frac{\Omega_{\tau}}{\Omega_{n}}>\frac{1}{\sigma-\tau}-\frac{1}{\sigma-\eta \tau},
$$

where the left hand side is the marginal benefit from trade and the right hand side is the marginal cost due to inefficient public spending worldwide. Clearly, condition (23) is more likely to be satisfied when $N, \nu$ and $\sigma$ are high. However, we can say more. When $\tau=0$, the right hand side of (23) becomes zero, so that welfare gains from small volumes of trade are guaranteed as long as $N>1$ and $\nu>0$. The reason is that the distortion is proportional to the trade share while the marginal benefit of trade does not depend on the level of international integration. Therefore, small volumes of trade bring about first order gains but only second order losses.

On the contrary, as $\tau \rightarrow 1$ the condition for welfare gains becomes:

$$
\nu(\sigma-1) \log \frac{N \Omega_{\tau}}{\Omega_{n}}>\frac{1+\eta}{\sigma-\eta},
$$

which may be violated if $\nu$ and $\sigma$ are low, even when $N$ is large. This suggests that trade must be beneficial at first, but may become welfare-reducing beyond a critical level. That is, there may be an optimal level of international integration. This case is illustrated in Figure 1, where the level of utility is plotted against the trade share $\tau$ for two different values of the gains from trade. Of course, if gains from trade are strong enough, they may always dominate the inefficiency from uncoordinated policies. It is also worth stressing 


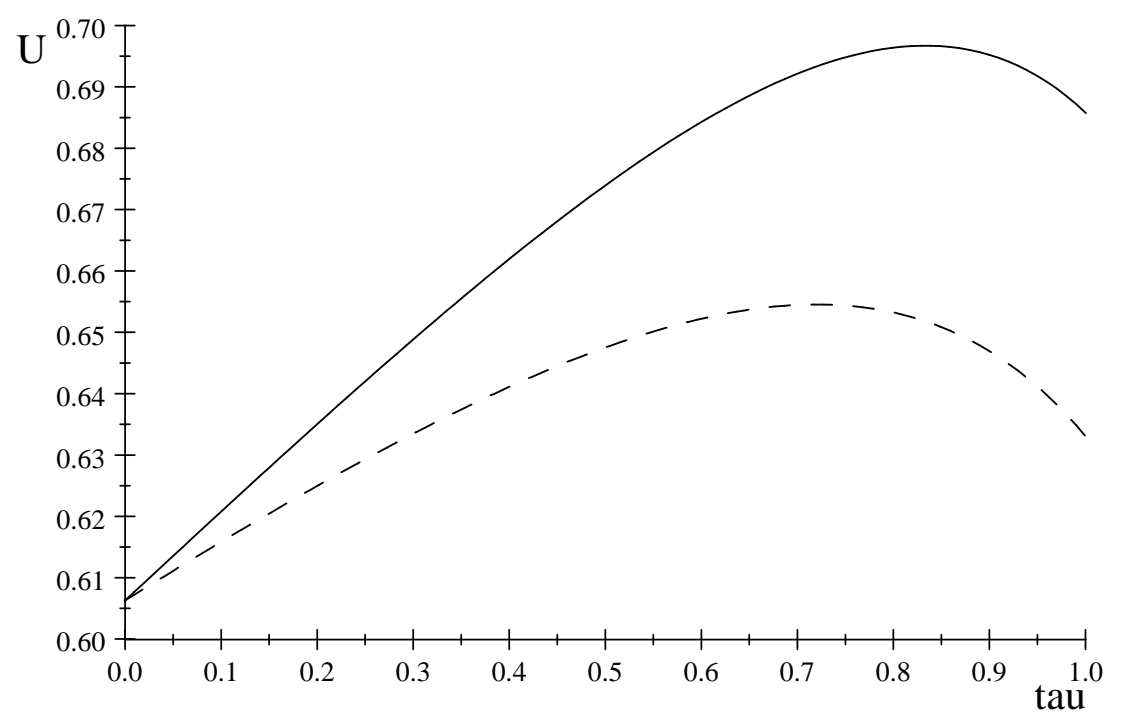

Figure 1: Trade Openness and Welfare. The lines are drawn for $\eta=0.8, \sigma=1.5$ and two values for the gains from trade: $\nu \log \left(N \Omega_{\tau} / \Omega_{n}\right)=0.3$ (solid line) and $\nu \log \left(N \Omega_{\tau} / \Omega_{n}\right)=$ 0.2 (broken line).

that in this model the gains from trade would always be non-negative for a world planner that fully internalizes the cost of taxation.

We close this section by summarizing the main implications of the model in the following Propositions.

Proposition 1 Openness can increase the size of governments through two channels: (1) the terms of trade externality, whereby trade lowers the domestic cost of taxation, and (2) the demand for insurance, whereby trade raises risk and public transfers. The first mechanism is inefficient from the standpoint of world welfare, while the second is optimal.

Proposition 2 The strength of the terms of trade externality relative to the demand for insurance is determined by the elasticity of substitution between domestic and foreign goods $\sigma$. As $\sigma \rightarrow 1$ the demand for insurance weakens, while the terms of trade externality becomes stronger. As $\sigma \rightarrow \infty$ the terms of trade externality vanishes, while the demand for insurance becomes stronger.

\section{Openness, Government Size and the Terms of Trade: The Evidence}

In this section, we look for evidence on the different mechanisms linking the size of government to openness. We start by showing that the positive correlation between openness 
and government size is remarkably robust, that exposure to terms of trade risk cannot explain variation in government size, and that openness does not increase transfers for social security and welfare. Next we show, using different approaches, that the link between openness and government size is contingent on a low elasticity of substitution between domestic and foreign goods. All these results support the explanation based on the terms of trade externality.

\subsection{Cross-Sectional Evidence}

We start by showing the relationship between government size, openness and other determinants in a cross-section of 143 countries. Our main measure of government size is general government consumption expenditure (abbreviated as government consumption) as a share of GDP, drawn from the Penn World Tables (release 6.1, PWT henceforth). This variable is a fairly good proxy for general government production, $g$, in our theoretical model. ${ }^{33}$ Our measure of openness is instead the share of imports plus exports over GDP, again from the PWT, and is consistent with both our model and the previous literature. ${ }^{34}$

Table 1 reports the first set of results. All variables except shares are in logs and are computed as averages for the years 1995-00. Following the previous literature, the openness ratio is lagged 5 years (it is the average for the period 1990-1994) and outlier countries with a trade share greater than 200 per cent are excluded from the sample. In column (1), we report a simple univariate regression of government consumption on the openness ratio, whose coefficient is large and significant beyond the one percent level. In column (2), we add per capita income and population (from the PWT). Income controls for the fact that the level of development may affect the availability of tax bases (the so-called Wagner's law) and the preference for public goods $(1-\eta$ in our model). We control for population to take instead account of Alesina and Wacziarg (1988)'s concern that the correlation between openness and government size may be driven by country size, as larger countries trade less and may have smaller governments due to scale economies in the provision of public goods. Our results show that income is negatively correlated

\footnotetext{
${ }^{33}$ General government production equals the value of all goods and services produced by employees of the State (at all levels of government) and distributed without charge or at prices which are not economically significant. General government consumption expenditure equals instead the general government production (less any fees collected) plus government purchases of goods and services that are distributed without charge to the community. See the UN report (2001) for a detailed analysis of the degree of comparability of these data across countries and overtime.

${ }^{34}$ Openness and government consumption are measured at current prices, as in most of the literature. A previous version of the paper, Epifani and Gancia (2007), showed that the results are unchanged when measuring these variables at constant prices.
} 
with government consumption. ${ }^{35}$ The link between country size and governments is also negative, though imprecisely estimated. ${ }^{36}$ More importantly, the openness coefficient is unaffected by the inclusion of these controls. In column (3), we exclude all Western European countries from the sample to take into account that these countries are typically very open and have large governments, and may therefore have a disproportionate influence on the openness coefficient. The results are essentially identical. In column (4), we add a full set of regional dummies (from the PWT). The openness coefficient is slightly reduced but is very precisely estimated notwithstanding the loss of degrees of freedom. In column (5), we add two variables that may capture the effect of external shocks on government spending: the standard deviation of terms of trade (lagged 5 years, from the PWT) and its interaction with openness. As suggested by Rodrik (1998), the interaction term is meant to capture the fact that more open economies may be more exposed to external shocks and hence demand more public insurance. Its coefficient is wrong signed, however, whereas the openness coefficient is still large and significant beyond the one percent level.

In column (6), we include other controls. First, we add the political regime using the proxy polity2 (drawn from the Polity IV dataset). ${ }^{37}$ Second, we control for financial restrictions to take into account that trade openness may be correlated with financial openness, which is unrelated to our theoretical framework. In particular, we add the black market premium (from the World Bank) and three dummy variables (from the IMF) taking value of one in the presence of current account restrictions, exchange rate restrictions and capital account restrictions, respectively. None of our political and financial controls can explain the cross-sectional variation in government consumption, whereas the openness coefficient is still large and very precisely estimated. Finally, in column (7) we include all the previous controls in the same specification and find no change in the results.

Regarding quantitative magnitudes, our estimates suggest that a 1 percentage point increase in the openness ratio brings about (roughly) a 0.15 percentage point increase in the government share of GDP. Together with the fact that openness increased on average by 42.5 percentage points in the second half of the last century, the growth of trade volumes alone can explain a 6.4 percentage points increase of $g$, i.e., more than one half of its total increase (11.8 percentage points).

\footnotetext{
${ }^{35}$ See also Ram (1987) on this point.

${ }^{36}$ The relationship between government and country size is theoretically ambiguous. On the one hand, Alesina and Wacziarg (1998) have shown that large countries should have smaller (larger) governments if the elasticity of substitution between private and public goods is lower (higher) than one. On the other, bigger countries may enjoy stronger terms of trade effects and thus have larger governments. It is thus not surprising that we do not find robust evidence on the impact of country size.

${ }^{37}$ This variable takes values in the range -10 (autocracy) to 10 (democracy) according to the degree of openness of political institutions.
} 
In columns (8)-(10), we rerun some of the above specifications using central government transfers for social security and welfare as the dependent variable. Investigating the relationship between openness and this type of expenditure is interesting because, if trade increases the demand for insurance, this may show up in a surge of public transfers. ${ }^{38}$ Our evidence does not lend support to this hypothesis, as the coefficient of openness is now small and insignificant or even wrong signed. Terms of trade variability does not seem to affect this kind of government expenditure either. Finally, column (11) shows that the results are not driven by the change in sample size when using data on social security and welfare: keeping the same sample and using government consumption as the dependent variable, we find that the openness coefficient is actually larger than in the broader sample (see column 5) and very precisely estimated.

Having shown that the cross-sectional correlation between openness and government consumption is robust, we now explore its determinants. Recall that a crucial feature of the model in Section 2 is that the terms of trade externality, which makes an expansion of the public sector less costly in open countries, is stronger for low elasticity $\sigma$. At the same time, a low $\sigma$ weakens the link between globalization and governments through the demand for insurance, due to the compensatory role of price adjustments. In order to provide an answer to the critical question of whether the positive correlation between openness and government size is contingent on $\sigma$ being high (the insurance hypothesis) or low (the externality view), we appeal to a simple strategy to build a proxy of $\sigma$ for individual countries. In particular, we exploit the fact that the elasticity of substitution is lower among differentiated goods. This suggests that countries exporting differentiated products face, on average, a less elastic demand than countries specialized in homogeneous commodities. Moving from this observation, we combine data on the structure of commodity exports with Rauch (1999)'s classification of traded goods into differentiated and homogenous products to compute the following variable:

$$
z_{i}^{r a}=\sum_{j} d_{j}^{r a} \frac{E X P_{i j}}{E X P_{i}},
$$

where $E X P_{i j}$ is country $i$ 's export in sector $j, E X P_{i}$ is total export and $d_{j}^{r a}$ is a dummy equal to one if industry $j$ 's output is classified as differentiated by Rauch. Thus, $z_{i}^{r a}$ measures the share of differentiated products in country $i$ 's export basket, and we use it

\footnotetext{
${ }^{38}$ Alesina and Wacziarg (1998) find that the correlation between government size and openness is stronger when using current central government expenditure (which includes transfers) instead of government consumption as the dependent variable. They therefore argue that the correlation may be driven by government transfers, but do not provide direct evidence on this. However, government consumption and central government expenditure differ substantially not only because of transfers but also because the latter excludes all self-financed expenditures by lower levels of government.
} 
as an inverse proxy for $\sigma$. We can then directly test how the correlation between openness and government size depends on $\sigma$ by simply introducing an interaction term between openness and $z_{i}^{r a}$. To compute $z_{i}^{r a}$, we use trade data at the 4-digit SITC (rev.2) level of disaggregation (from the UN-Comtrade dataset), so as to match Rauch's classification. ${ }^{39}$ We use data for the year 2000 to maximize sample size (125 observations overall). A table listing the value of $z_{i}^{r a}$ for each country is reported in the Appendix.

With this new variable at hand, in Table 2 we reexamine the cross-sectional evidence on the correlation between openness and government size. In column (1), we regress government consumption on $z_{i}^{r a}$ and openness only, and find that the openness coefficient is unaffected by the inclusion of the new control, which turns out insignificant. In column (2), we perform our crucial test by adding the interaction between openness and $z_{i}^{r a}$. Strikingly, the coefficient of openness drops to zero, whereas the coefficient of the interaction term is positive, large and significant beyond the one percent level. This suggests that openness is positively correlated with the size of government only for countries exporting differentiated goods. In column (3), we add our baseline controls, income and population, and find that the results are unaffected. In column (4), we add a full set of regional dummies: the fit improves substantially and our results become stronger.

One possible concern is that our results may be driven by the fact that our proxy is correlated with income and institutional quality (the simple correlation of $z_{i}^{r a}$ with these variables is roughly 0.4 ). In column (5), we therefore control for the interaction between openness and income, whereas in column (6) we use Rule of Law (from Kaufmann, Kraay and Mastruzzi, 2005) to proxy for institutional quality, and interact it with openness. In both specifications, the coefficients of openness and the new controls are insignificant, suggesting the correlation between openness and government size to be independent of the level of development. In contrast, the sign and significance of the coefficient of the interaction between openness and $z_{i}^{r a}$ rise even further.

In columns (7) and (8), we control for terms of trade variability using two different measures: in the former we use the standard deviation of terms of trade, in the latter the standard deviation of the log change of the terms of trade over the entire period 1960-2000. We also interact these variables with the openness ratio. Our main results are unchanged, whereas the interactions with terms of trade variability are wrong signed. In column (9), following Rodrik (1998), we include the normalized Herfindahl index of export concentration and its interaction with openness. ${ }^{40}$ Both controls turn out insignificant

\footnotetext{
${ }^{39} \mathrm{~A}$ good is defined as differentiated if it is neither sold on an organized exchange, nor reference priced in a trade publication. This classification is widely used in the literature.

${ }^{40}$ This term may capture the fact that highly concentrated exports may increase the exposure to risk. We use data for the year 2000 from the UNCTAD-Handbook of Statistics to compute it.
} 
while leaving the other results unchanged. Finally, in column (10) we include all controls in the same specification and find that the coefficient of the interaction between $z_{i}^{r a}$ and openness is unaffected, whereas most of the other controls are insignificant.

Is $z_{i}^{r a}$ a good proxy for $1 / \sigma$ in our model? We address the concerns on the quality of $z_{i}^{r a}$ by constructing an alternative proxy using a different source of information on the cross-industry variation in elasticities of substitution. In particular, we appeal to Broda and Weinstein (2006)'s recent estimates of the elasticity of substitution across 4-digit SITC industries to compute, for each country in the sample, the following variable:

$$
z_{i}^{b w}=\sum_{j} \frac{1}{\sigma_{j}^{b w}} \frac{E X P_{i j}}{E X P_{i}}
$$

where $\sigma_{j}^{b w}$ is Broda and Weinstein's estimate of the elasticity of substitution in sector $j$. Note that the only difference between $z_{i}^{r a}$ and $z_{i}^{b w}$ is that in the latter we have replaced a dichotomous indicator, $d_{j}^{r a}$, of whether or not an industry's output is differentiated with a point estimate of an industry's elasticity of substitution. The proxy $z_{i}^{b w}$ is therefore even more closely related to our model, although possibly subject to larger measurement error. The simple correlation between $z_{i}^{r a}$ and $z_{i}^{b w}$ is reassuringly high (0.50). In Table 3, we rerun the same specifications of Table 2 using $z_{i}^{b w}$ instead $z_{i}^{r a}$. Note that the pattern of results is essentially unchanged: when introducing the interaction between openness and $z_{i}^{b w}$, the coefficient of openness becomes small and insignificant and the results are not affected by the other control variables. The coefficient of the interaction between openness and $z_{i}^{b w}$ is instead always large and significant at conventional levels, although slightly less precisely estimated in some specifications. ${ }^{41}$

\subsection{Panel-Data Evidence}

So far, we have relied on cross-sectional variation to estimate the coefficients of interest. Yet, some of our variables are available from the Penn World Tables over a period of half a century (1950-2000). Hence, to fully exploit the available information, we now complement our previous analysis by reporting panel-data results. ${ }^{42}$ This also allows us

\footnotetext{
${ }^{41}$ Using both $z_{i}^{r a}$ and $z_{i}^{b w}$, our results are unchanged when dropping all the Western European countries from the sample. This robustness check is not reported to save space.

${ }^{42}$ This also allows us to complement the evidence in Rodrik (1998) and Alesina and Wacziarg (1998), which is mainly cross-sectional. Many other empirical studies have investigated the determinants of the size of the public sector. A review of this literature is beyond the scope of this paper. For the interested reader, we refer to the important contributions of Persson and Tabellini (1999 and 2003) and Alesina and Glaeser (2004).
} 
to control for unobserved country heterogeneity that does not vary over time. ${ }^{43}$ We start, as in the previous section, by showing evidence on the correlation between openness and government size and then test whether it is contingent on a low elasticity of substitution, as suggested by our previous results.

Table 4 reports Fixed-Effects within estimates using government consumption (columns 1-5 and 9) and central government expenditure for social security and welfare (columns 6-8) as the dependent variables. All variables are computed as five-year averages from 1950-54 to 1990-94 and as six-year averages in the last period (1995-00). The openness ratio is lagged one period (except in the dynamic specifications of columns 2 and 7 ), and outlier countries with a trade share greater than 200 percent are excluded. In column (1), we control for per capita income, population and time dummies. ${ }^{44}$ The coefficient of openness is positive and significant beyond the one percent level. In column (2), we examine a dynamic specification in which we also control for lagged government consumption to take into account that public spending is generally persistent and may therefore react slowly to changes in the economic environment. ${ }^{45}$ As is well known, Fixed-Effects estimates are severely biased when the lagged dependent variable is included among the regressors and we therefore report bias-corrected estimates according to Kiviet (1995). ${ }^{46}$ The results are strong: the coefficient of openness is still very precisely estimated, whereas those of income and population are now insignificant. The coefficient of the lagged dependent variable is also large and significant, confirming that public spending is persistent. These estimates imply that the long-run impact of openness on government consumption $(0.039 /(1-0.84)$

\footnotetext{
${ }^{43}$ Although our empirical analysis relies on different approaches to address the endogeneity due to omitted variables, it does not address the direction of causality between openness and government size. On this respect, we do not have much to add to Rodrik (1998), who showed that openness in 1960 is a good predictor for the subsequent growth of government size and that the correlation holds when openness is instrumented with geographical variables. These findings, that are not replicated to save space, support our prior that public spending is more endogenous than openness. In any event, our crucial test does not require sorting causality, as the terms of trade explanation can be made consistent with reverse causality too: if openness had an endogenous component, countries with a strong preference for public goods would prefer to be open. The resulting correlation would still be contingent on a low elasticity.

${ }^{44}$ The inclusion of time-dummies is not sufficient to avoid spurious results if the main variables are non-stationary. On this respect, we have performed panel unit root tests on our measures of openness and government consumption using the $t$-test based on OLS estimates. The test is advocated, among others, by Bond et al. (2002) due to its relatively high power. The null hypothesis of a unit root is always rejected at the one percent level.

${ }^{45}$ So far, we have only taken into account of this fact by using the lagged value of the openness ratio.

${ }^{46}$ Kiviet (1995) derives an approximate formula for the small-sample bias of the Fixed-Effects estimator. An alternative would be to use Generalized Method of Moments (GMM) estimators. The main advantage of Kiviet's estimator is that it exploits the fact that the Fixed-Effects estimator, although seriously biased, has a much smaller variance than the consistent GMM estimators, implying that bias-corrected FixedEffects estimates are generally more efficient. We also estimated column (2) in the table by (uncorrected) Fixed-Effects and by GMM. In both cases the openness coefficient is positive and significant, but GMM estimates prove very large and sensitive to the details of the estimation procedure (implicitly confirming Kiviet's results).
} 
$=0.24)$ is roughly of the same order of magnitude as in our cross-sectional regressions. In column (3), we control for the standard deviation of the terms of trade (lagged one period) and its interaction with openness: both controls are insignificant and leave the openness coefficient unaffected. In column (4), we add polity and financial controls. The coefficients of the black market premium and capital account restrictions are now positive and significant, which is consistent with the idea that financial globalization promotes tax competition and thus smaller governments. More important for our purposes, the openness coefficient is unaffected. In column (5), we add country-specific linear trends and find that the size and significance of the openness coefficient increase. ${ }^{47}$ In columns (6)-(8), we rerun some of the above regressions using government transfers for social security and welfare as the dependent variable. The coefficient of openness drops to zero or even becomes negative, confirming our previous result that openness is unrelated to public transfers. Once again, the result is not driven by the change in sample size: in column (9), we use government consumption as the dependent variable for the same sample and find that the openness coefficient is large and significant. ${ }^{48}$

Finally, and most importantly, in Tables 5 and 6 we test whether the positive association between openness and government consumption is contingent on a low elasticity of substitution. We use $z_{i}^{r a}$ to proxy for $1 / \sigma$ in Table 5 , and $z_{i}^{b w}$ in Table 6 . In Table 5, we start with a univariate regression of government consumption on the openness ratio (column 1) to show that simply adding the interaction between openness and $z_{i}^{r a}$ (column 2) causes the openness coefficient to become small and insignificant. The coefficient of the interaction term is instead positive, large and significant at the 2 percent level. In column (3), we add our standard controls (income, population and time dummies) and find that the coefficient of the interaction term grows larger and significant beyond the one percent level, whereas the openness coefficient is still small and insignificant. In columns (4)-(8), we show that the results do not change when adding, individually or altogether, the interactions of openness with income, institutional quality, terms of trade variability and export concentration. In Table 6, finally, we rerun the same specifications using $z_{i}^{b w}$ instead of $z_{i}^{r a}$ and find equally strong results: the coefficient of openness is never positive and significant, whereas the coefficient of the interaction between openness and $z_{i}^{b w}$ is always positive, very large and significant beyond the one percent level. ${ }^{49}$

\footnotetext{
${ }^{47}$ Note that adding country-specific linear trends turns the coefficient of country size from positive to negative, probably suggesting that country size may capture the effect of a time trend in Fixed-Effects regressions.

${ }^{48}$ A previous version of the paper, Epifani and Gancia (2007), showed that the positive association between openness and government consumption holds also in the sub-periods 1950-75 and 1975-00, and that it has strengthened overtime.

${ }^{49}$ Once again, using both $z_{i}^{r a}$ and $z_{i}^{b w}$, our results are unchanged when dropping all Western European
} 
We now look for direct evidence on the terms of trade externality. A crucial feature of our theory is that a 1 percent increase in private output induces a $1 / \sigma$ percent fall in the terms of trade (see equation 4): we now show that the data are consistent with this notion that fast growing countries experience a terms of trade deterioration, and hence that $\sigma$ is not too high for the average country. To start with, we use equation (4) to estimate a cross-country average of the elasticity of substitution between domestic and foreign goods. In particular, we estimate cross-sectional regressions of the form:

$$
d p_{i}=\alpha+\gamma d y_{i}+X_{i}^{\prime} \delta+\varepsilon_{i}
$$

where $d p_{i} \equiv d \ln \left(p_{i} / Q\right)$ is the growth rate of country $i$ 's terms of trade, $\alpha$ is a constant term, $d y_{i} \equiv d \ln \left(y_{i} / Y\right)$ is the growth rate of country $i$ 's private output relative to world output, $X_{i}^{\prime}$ is a vector of controls and $\varepsilon_{i}$ is a random disturbance. Our parameter of interest, $\gamma=-1 / \sigma$, captures the terms of trade externality.

We estimate (25) for the period 1960-2000 (or nearly so, depending on data availability). One concern with terms of trade data is that their movements are affected by global changes in commodity prices that may be unrelated to country-specific developments, possibly hiding the mechanism we want to test. For instance, Backus and Crucini (2000) have shown that terms of trade movements in the US are dominated by the behavior of oil prices. Therefore, in order to better isolate terms of trade changes due to a country's relative growth performance, we net out the effect of changes in the fuel-prices from the growth rate of terms of trade. ${ }^{50}$ Following Backus and Crucini (2000), non-fuel terms of trade $\left(T o T^{n f}\right)$ can be expressed as:

$$
T o T_{i}^{n f}=\frac{P_{i}^{x}}{P_{i}^{m}} \frac{S_{i}^{x n f}}{S_{i}^{m n f}} \frac{q_{i}^{x}}{q_{i}^{m}},
$$

where $P_{i}^{x} / P_{i}^{m}$ are the overall terms of trade, namely, the ratio of export prices, $P_{i}^{x}$, to import prices, $P_{i}^{m} ; S_{i}^{x n f}\left(S_{i}^{m n f}\right)$ is the value of non-fuel exports (imports) as a share of total exports (imports); $q_{i}^{x}\left(q_{i}^{m}\right)$ is the ratio of the quantity of non-fuel exports (imports) to the quantity of total trade. As in Backus and Crucini, and given the data at hand, we assume the ratio $q_{i}^{x} / q_{i}^{m}$ to be constant overtime, thereby ignoring time variation in the physical quantity of fuel to non-fuel trade. Data on the average growth rate of overall

\footnotetext{
countries from the sample.

${ }^{50} \mathrm{~A}$ previous version of the paper, Epifani and Gancia (2007), provided evidence on the terms of trade externality using data on the growth rate of overall terms of trade.
} 
terms of trade are from the PWT, whereas data on the average growth rate of non-fuel import and export shares are drawn from the UN Comtrade database.

Output of the private sector is measured as real GDP net of government consumption. Note that the growth rate of world output, $Y$, is constant across countries and is therefore absorbed by the constant term, $\alpha$. However, due to transport costs and other trade barriers, the set of trading partners may vary across countries, implying that the growth rate of country $i$ 's trading partners does not coincide with the growth rate of world output. To cope with this, as a robustness check, we will compute $Y$ for each country as the tradeweighted average of its commercial partners' GDP. This data is drawn from the World Bank.

We estimate (25) by Ordinary Least Squares (OLS) and by Instrumental Variables (IV). OLS estimates raise a standard identification problem, as $\sigma$ represents a parameter of world demand for domestic products. To identify it, we should isolate variations in domestic supply orthogonal to changes in the terms of trade. Otherwise, demand shocks (e.g., preference shifts in favor of a country's exports) would tend to generate a positive correlation between output growth and changes in the terms of trade, biasing $\gamma$ towards zero and $\sigma$ towards infinite. OLS estimates mixing demand and supply changes can however provide a useful lower bound for the terms of trade externality.

As for IV estimates, we follow Acemoglu and Ventura (2002) in instrumenting the growth rate of output with the right hand side variables of a convergence equation $\grave{a}$ la Barro and Sala-i-Martin (1995). The idea is to isolate the source of variation in growth rates that is explained by a country's distance from its steady-state and use it to estimate $\sigma$, under the assumption that growth due to convergence is exogenous to the terms of trade. We will therefore estimate (25) by Two-Stage Least Squares (2SLS) using a first stage regression for $d y_{i}$ of the following type:

$$
d y_{i}=\vartheta+\beta y_{0 i}+Z_{i}^{\prime} \varphi+X_{i}^{\prime} \psi+\xi_{i},
$$

where $y_{0 i}$ is the $\log$ of private output at the beginning of the period, $\vartheta$ is a constant, $Z_{i}^{\prime}$ is a set of additional excluded instruments, $X_{i}^{\prime}$ is the vector of included instruments and $\xi_{i}$ is a random disturbance. $\beta<0$ captures the speed of conditional convergence toward the steady state. We start by using only $y_{0 i}$ as an excluded instrument. Thus, our identification relies on the exogeneity of GDP in 1960 to the subsequent growth of the terms of trade. Then, to gain efficiency, we add some standard determinants of steady state income among the excluded instruments $Z_{i}^{\prime}$ and check their exogeneity with the overidentification test. Finally, we include the growth rate of the public sector among the covariates $X_{i}^{\prime}$ in order to test another piece of our mechanism: that the growth of the 
public sector crowds out private output (its expected sign is therefore negative in the first stage regressions) and that it has no other direct effect on the terms of trade (implying a zero coefficient in the second stage regressions).

Table 7 reports the main results. We start with three univariate OLS regressions: in column (1) we regress the growth rate of non-fuel terms of trade on the growth rate of total private GDP, in column (2) we use the growth rate of private GDP per capita and in column (3) the growth rate of private per capita GDP relative to trading partners. The results are essentially identical: the point estimates suggest a 1 percent increase in the growth rate of private output to bring a 0.32 percent fall in the terms of trade, implying an elasticity of substitution, $\sigma$, of 3 .

In columns (4)-(7) we report Instrumental Variables estimates. The mid panel displays Two-Stage Least Squares estimates for the growth rate of non-fuel terms of trade. The first line gives estimates of $\gamma=-1 / \sigma$. The bottom panel displays the first stage regressions for the growth rate of private GDP and two tests for the quality of our instruments: the value of the $F$-statistic of excluded instruments and the $p$-value of Hansen's $J$-statistic of overidentifying restrictions. For comparison, the upper panel reports OLS estimates of $\gamma$. In column (4), we instrument the growth rate of private per capita GDP with the $\log$ of its initial level. We also add, as included instruments, two proxies for the initial level of human capital, i.e., the logs of average years of schooling and of life expectancy. ${ }^{51}$ As expected, the estimated terms of trade externality is larger than in OLS regressions, although it is significant at the 10 percent level only. The coefficients of the two proxies for initial human capital are instead close to zero and statistically insignificant in the second stage regression, suggesting that they have no direct impact on the growth of terms of trade. In column (5), we treat them as excluded instruments. The oveidentification test is insignificant and the $F$-statistic is very high, suggesting our instruments to be valid and relevant. In this case, the terms of trade externality is very precisely estimated. In column (6), we add two included instruments: the growth rate of average years of schooling and the growth rate of the government share of GDP. Consistent with our model, the growth rate of government consumption has a large and statistically significant negative impact on the growth rate of private output in the first stage regression. In contrast, it has no significant impact on the terms of trade in the second stage, suggesting that government size affects the terms of trade only through its effect on private output. ${ }^{52}$ Moreover, the

\footnotetext{
${ }^{51}$ These variables are sourced, respectively, from the Barro-Lee database and the World Bank. In order to save observations, when possible we have replaced missing values with regional averages.

${ }^{52}$ These results are interesting and in line with our theory, but must be interpreted with caution, since government output is endogenous. It is reassuring, however, that the estimated terms of trade effect is unchanged and that our instruments pass both tests.
} 
estimated terms of trade externality is still significant at the one percent level, whereas the growth of schooling proves insignificant in both the first and second stage regressions. In column (7), we rerun the same specification using the growth rate of private per capita GDP relative to trading partners and find even stronger results.

In sum, our IV estimates imply that a 1 percent increase in the growth rate of GDP brings about a $0.39-0.45$ percent fall in the terms of trade, consistent with an elasticity of substitution between 2.2 and 2.6. This result is in line with the value $(\sigma \approx 2.6)$ found by Acemoglu and Ventura (2002) using different data and the estimates in Broda and Weinstein (2006). ${ }^{53}$ Finally, by comparing IV and OLS results, we can note that OLS estimates of the terms of trade externality are always smaller than IV estimates, as expected, though still significant. This suggests that IV results are not an artifact of the instrumenting strategy. ${ }^{54}$

Having shown that the terms of trade externality is strong for the average country, we now reestimate it across country groups to perform a final test of our theory: to show that the terms of trade externality is stronger for those countries that exhibit a stronger correlation between openness and government size. To this end, we split our sample into two groups of equal size: the first group includes the countries that contribute relatively more to estimating a positive correlation between openness and government size, while the second group includes all other countries. ${ }^{55}$ Countries belonging to the two groups are listed in the Appendix. Those in the first group tend to be larger (this group includes all the G-8 countries plus China), slightly richer, and have a higher propensity to export differentiated products. All these characteristics suggest that they might indeed be less price takers. In contrast, countries that have experienced export led growth (e.g., the Asian Tigers) belong to the second group. This is not surprising, as restraining the export sector does not seem the best policy for countries that achieve high growth by promoting exports. Finally, data quality (according to the PWT documentation) is very similar across groups.

In Table 8, we estimate the elasticity of substitution for the two sets of countries using the same specifications as in Table 7. The table displays OLS estimates of $\gamma$,

\footnotetext{
${ }^{53}$ Working with disaggregated data for the period 1972-2001, Broda and Weinstein (2006) report a median value for the elasticity of substitution between US varieties in the interval 2.7 - 3.6.

${ }^{54}$ In a previous version of the paper, Epifani and Gancia (2007), we also provide evidence that terms of trade externalities have grown stronger over time, a result consistent with the independent findings of Broda and Weinstein (2006). Thus, even if one may expect globalization per se to increase demand elasticities, we do not have evidence of any weakening of terms of trade effects.

${ }^{55}$ To split the sample, we started from a baseline Fixed-Effects regression of government consumption on openness, income, population and time dummies. Then, for each country, we computed the average difference between the estimated coefficient for openness when the observation is included and excluded, scaled by the estimated standard error of the coefficient (the so-called DF beta). Countries with a higher DF beta are those whose inclusion in the sample has a larger positive impact on the coefficient of openness.
} 
2SLS regressions and first stage statistics. Panel a) shows the results for the sub-sample of countries with a stronger correlation between openness and government size. OLS estimates of the terms of trade externality are always large and significant at the 1 or 5 percent levels, implying a value of the elasticity of substitution between 1.7 and 2.1. 2SLS estimates are even larger and very stable across specifications, implying a value of $\sigma \approx 1.5$. They are also significant at the 1 to 5 percent levels, except in one specification (see column 4). ${ }^{56}$ Considering the sub-sample of countries with a weaker correlation between openness and government size (panel b), the results are strikingly different: IV and OLS estimates of the terms of trade externality are always small, insignificant, and in some cases wrong signed. ${ }^{57}$ In conclusion, all our empirical results consistently support the view that openness increases government size only for countries that are not price takers.

\section{Conclusion}

We close with some remarks on the policy implications of our findings. It is well-known that governments in a global economy may have incentives to use tariffs to manipulate the terms of trade in their favor. By removing these incentives, the WTO principles may provide a solution to the inefficiencies that would arise under non-cooperative tariff setting (Bagwell and Staiger, 1999). As shown in this paper, however, even the simplest form of domestic taxation may produce similar terms of trade effects. Are then the WTO rules adequate to deal with this problem as well? We believe they are not, because fiscal policies are seen as a matter of national sovereignty that goes beyond the WTO jurisdiction. Other widespread forms of international economic integration do not deal with this problem either. For example, preferential trade agreements and custom unions do not involve political coordination on fiscal issues. As a result, market integration and political cooperation have followed rather independent routes.

By imposing constraints on fiscal policy to member states, the EU may appear in this respect an exception. Even in this case, however, we think that too little has been done. Much of the debate on the coordination of fiscal policies has been centred on the Stability and Growth Pact that imposes limits to budget deficits and debt. Even if those limits may be given some economic rationale, they do not provide a solution to the inefficiency illustrated in this paper, because the latter arises from too high a level of public spending

\footnotetext{
${ }^{56}$ Not coincidentally, in this specification the $F$-statistic of excluded instruments reaches a minimum, falling marginally below the threshold value of 10 . Otherwise, the first stage statistics support our choice of instruments as the $F$-statistic is high and the $J$-statistic is always insignificant.

${ }^{57}$ First stage statistics seem to support our choice of instruments also in this sub-sample.
} 
and not from excessive debt or deficits. Thus, while the EU may provide an appropriate institutional framework to achieve policy coordination, measures so far adopted seem neither necessary nor sufficient to correct fiscal externalities due to globalization.

\section{REFERENCES}

[1] Acemoglu, Daron and Jaume Ventura (2002). "The World Income Distribution," Quarterly Journal of Economics, 117, 659-694.

[2] Alesina, Alberto and Edward L. Glaeser (2004). Fighting Poverty in the U.S. and Europe: A World of Difference, Oxford University Press, New York.

[3] Alesina, Alberto and Roberto Perotti (1997). "The Welfare State and Competitiveness," American Economic Review, 89, 921-937.

[4] Alesina, Alberto and Romain Wacziarg (1998). "Openness, Country Size and Government," Journal of Public Economics, 69, 305-321.

[5] Andersen, Torben M., Bo S. Rasmussen and Jan R. Sorensen (1996). "Optimal Fiscal Policy in Open Economies with Labor Market Distortions," Journal of Public Economics, 63, 103-117.

[6] Andersen, Torben M. (2004). "Challenges to the Scandinavian Welfare Model," European Journal of Political Economy, 20, 743-754.

[7] Andersen, Torben M. (2008). "The Scandinavian Model - Prospects and Challenges," International Tax and Public Finance, 15, 45-66.

[8] Bagwell, Kyle and Robert W. Staiger (1999). "An Economic Theory of GATT," American Economic Review, 89, 215-248.

[9] Bagwell, Kyle and Robert W. Staiger (2006). "What Do Trade Negotiators Negotiate About? Empirical Evidence from the World Trade Organization," mimeo, Columbia and Stanford University.

[10] Backus, David and Mario Crucini (2000). "Oil Prices and the Terms of Trade," Journal of International Economics, 50, 185-213.

[11] Barro, Robert and Xavier Sala-i-Martin (1995). Economic Growth, McGraw-Hill, New York.

[12] Benassy, Jean-Pascal (1998), "Is There Always Too Little Research in Endogenous Growth with Expanding Product Variety?," European Economic Review, 42, 61-69. 
[13] Boadway, Robin, Shlomo Maital and Martin Prachowny (1973). "Optimal Tariffs, Optimal Taxes and Public Goods," Journal of Public Economics, 2, 391-403.

[14] Bond, Stephen, Céline Nauges and Frank Windmeijer (2002). "Unit Roots and Identification in Autoregressive Panel Data Models: A Comparison of Alternative Tests," mimeo, Institute for Fiscal Studies, London.

[15] Broda, Christian, Nuno Limao and David E. Weinstein (2006). "Optimal Tariffs: The Evidence," NBER WP 12033.

[16] Broda, Christian and David E. Weinstein (2006). "Globalization and the Gains from Variety," Quarterly Journal of Economics, 121, 541-585.

[17] Cameron, David R. (1978). "The Expansion of the Public Economy: A Comparative Analysis," American Political Science Review, 72, 1243-1261.

[18] Cole L. Harold and Maurice Obstfeld (1991). "Commodity Trade and International Risk Sharing: How Much Do Financial Markets Matter?" Journal of Monetary Economics, 28, 3-24.

[19] Corsetti, Giancarlo and Paolo Pesenti (2001). "Welfare and Macroeconomic Interdependence," Quarterly Journal of Economics, 116, 421-446.

[20] Devereux, Michael B. (1991). "The Terms of Trade and the International Coordination of Fiscal Policy," Economic Inquiry, 29, 720-736.

[21] Epifani Paolo and Gino Gancia (2007). "On Globalization and the Growth of Governments," CEPR DP 6065.

[22] European Commission (1997). Single Market Review: Public Procurement, Kogan Page, London.

[23] Fatás, Antonio and Ilian Mihov (2001). "Government Size and Automatic Stabilizers: International and Intranational Evidence," Journal of International Economics, 55, $3-28$.

[24] Feenstra, Robert C. (2004). Advanced International Trade, Princeton University Press.

[25] Galí, Jordi (1994). "Government Size and Macroeconomic Stability," European Economic Review, 38, 117-132.

[26] Galí, Jordi and Tommaso Monacelli (2005). "Optimal Fiscal Policy in a Monetary Union," mimeo, CREI and Universita' Bocconi. 
[27] Garen, John and Kathleen Trask (2005). "Do More Open Countries Have Bigger Governments? Another Look," Journal of Development Economics, 77, 533-551.

[28] Garrett, Geoffrey (2001). "Globalization and Government Spending around the World," Studies in Comparative International Development, 35, 3-29.

[29] Goldberg, Penny Koujianou and Michael M. Knetter (1997). "Goods Prices and Exchange Rates: What Have We Learned?" Journal of Economic Literature, 35, 12441272 .

[30] Gordon, Roger H. (1983). "An Optimal Taxation Approach to Fiscal Federalism," Quarterly Journal of Economics, 98, 567-586.

[31] Grossman, Gene and Elhanan Helpman (1994). "Protection for Sale," American Economic Review, 84, 833-850.

[32] Hassler, John, Jose V. Rodriguez-Mora, Kjetil Storesletten and Fabrizio Zilibotti (2003). "The Survival of the Welfare State," American Economic Review, 93, 87-112.

[33] Islam, Muhammad Q. (2004). "The Long Run Relationship between Openness and Government Size: Evidence from Bounds Test," Applied Economics, 36, 995-1000.

[34] Kaufmann, Daniel, Aart Kraay, and Massimo Mastruzzi (2005). "Governance Matters IV: Governance Indicators for 1996-2004," mimeo, The World Bank, Washington.

[35] Kiviet, Jean-Marie (1995). "On Bias, Inconsistency and Efficiency of Various Estimators in Panel Data Models," Journal of Econometrics, 68, 53-78.

[36] Limao, Nuno (2006). "Preferential Trade Agreements as Stumbling Blocks for Multilateral Trade Liberalization: Evidence for the U.S." American Economic Review, 96, 896-914.

[37] Lindbeck, Assar and Jorgen Weibull (1993). "A Model of Political Equilibrium in a Representative Democracy," Journal of Public Economics, 51, 195-209.

[38] Monacelli, Tommaso and Roberto Perotti (2008). "Openness and the Sectoral Effects of Fiscal Policy," Journal of the European Economic Association, forthcoming.

[39] Newbery, David M. and Joseph E. Stiglitz (1984). "Pareto Inferior Trade," Review of Economic Studies, 51, 1-12.

[40] Persson, Torsten and Guido Tabellini (1992). "The Politics of 1992: Fiscal Policy and European Integration," Review of Economic Studies, 59, 689-701. 
[41] Persson, Torsten and Guido Tabellini (1995). "Double-Edged Incentives: Institutions and Policy Coordination," Chapter 38 in Grossman, G. and K. Rogoff (eds.), Handbook of International Economics, Vol III, North-Holland, Amsterdam.

[42] Persson, Torsten and Guido Tabellini (1999). "The Size and Scope of Government: Comparative Politics with Rational Politicians," European Economic Review, 43, 699735.

[43] Persson, Torsten and Guido Tabellini (2000). Political Economics, MIT Press, Cambridge MA.

[44] Persson, Torsten and Guido Tabellini (2003). The Economic Effects of Constitutions, MIT Press, Cambridge MA.

[45] Ploeg, Frederick van der (1987). "Coordination of Optimal Taxation in a TwoCountry Equilibrium Model," Economics Letters, 24, 279-285.

[46] Ram, Rati (1987). "Wagner's Hypothesis in Time-Series and Cross-Section Perspectives: Evidence from "Real" Data for 115 Countries," Review of Economics and Statistics, 69, 194-204.

[47] Rauch, James E. (1999). "Networks versus Markets in International Trade," Journal of International Economics, 48, 7-35.

[48] Rodrik, Dani (1997). Has Globalization Gone Too Far?, Institute for International Economics, Washington, DC.

[49] Rodrik, Dani (1998). "Why Do More Open Economies Have Bigger Governments?" Journal of Political Economy, 106, 997-1032.

[50] Turnovsky, Stephen (1988). "The Gains from Fiscal Cooperation in a Two Commodity Real Trade Model," Journal of International Economics, 25, 111-127.

[51] United Nations (2001). World Public Sector Report: Globalization and the State, United Nations, New York.

[52] Vilarrubia, Josep M. (2006). "Neighborhood Effects in Economic Growth," Banco de Espana WP 0627.

[53] Wacziarg, Romain and Karen Horn Welch (2003). "Trade Liberalization and Growth: New Evidence," NBER WP 10152.

[54] Wilson, John D. (1987). "Trade, Capital Mobility and Tax Competition," Journal of Political Economy, 95, 835-856. 


\section{Appendix}

\subsection{Home Bias in Government Consumption}

We use the OECD Input-Output Tables, available for a sample of 14 developed and developing countries around the year 2000, to measure the degree of home bias in government consumption. Table A1 reports, for each country in the sample, government import as a share of government consumption and total import as a share of total GDP. Note that economy-wide import shares are several orders of magnitude greater than those of the public sector in all countries. These figures are consistent with those reported in other studies. For instance, according to the European Commission (1997), imports accounted for less than $2 \%$ of public purchases in EU countries in the late '80s (compared to economy-wide import shares ranging from 25 to 45). Inspection of the Input-Output Tables reveals that an important reason why government spending is home-biased is that, consistent with our model, public goods and services are produced by relying disproportionately on domestic labor: purchases of intermediate goods by the public sector are in fact a small share of government consumption (hardly greater than 10\%) in most countries.

\subsection{Openness and the Size of Government with Asymmetric Countries}

We show how to modify the model to allow for cross-country differences in all the parameters. For simplicity, we limit to partial equilibrium in that we do not solve for world quantities. This is without loss of generality since any (small) country takes world production as given. First, we allow the range of traded goods to vary across countries, so that in different countries different sectors may produce for world markets. For trade to be feasible, we assume that for any good that is traded in a country there is a positive number of countries where products from the same sector are traded as well. ${ }^{58}$ This means that varieties produced in a given sector can be nontraded everywhere, traded by a subset of countries only, or traded by all countries. We denote the number of countries where industry $j$ is traded as $N_{j}$ and the total mass of traded sectors in country $i$ as $\tau_{i}$.

Second, we assume that $\sigma$ varies across goods but that a country only trades goods with the same $\sigma$. This is intended as a shortcut for a more general model where $\sigma$ varies across exports and the $\sigma$ we consider represents an appropriate country-average. The important feature we want to capture here is that countries may differ in their ability to affect the terms of trade due to the product characteristics of their export. Our assumption delivers this in the most parsimonious way. Finally, we allow the preference for private

\footnotetext{
${ }^{58}$ We also maintain the assumption that a country is always small in international markets.
} 
consumption, $\eta_{i}$, to vary across countries.

Let us consider country $i$ and, for simplicity, abstract from uncertainty $(\epsilon=0)$. Consumption of goods produced in sector $j$ can be found as follows. If good $j$ is nontraded, then consumption is equal to domestic production:

$$
Y_{i, j}=L_{i, j}
$$

If good $j$ is traded, domestic consumption equals disposable income divided by the price index in sector $j$ :

$$
Y_{i, j}=\frac{w_{i}}{Q_{j}} L_{i}\left(1-g_{i}\right)=\left[\left(L_{i, j}\right)^{-1}\left(N_{j}\right)^{\nu \sigma-\nu-1} Y_{w, j}\right]^{1 / \sigma} L_{i}\left(1-g_{i}\right) .
$$

Next, we need to solve for $L_{i, j}$. In nontraded sectors, domestic expenditure equals the value of domestic production, $\left(1-g_{i}\right) w_{i} L_{i}=w_{i} L_{i, j}$, so that $L_{i, j}=\left(1-g_{i}\right) L_{i}$. Labor market clearing requires:

$$
\int_{0}^{1} L_{i, j} d j=\left(1-\tau_{i}\right)\left(1-g_{i}\right) L_{i}+\tau_{i} L_{i, \tau}=\left(1-g_{i}\right) L_{i}
$$

where $L_{i, \tau}$ is employment in the average traded sector. Solving:

$$
L_{i, \tau}=\left(1-g_{i}\right) L_{i}
$$

Labor allocation across traded sectors will vary in an asymmetric equilibrium. Equalizing wages in any two traded sectors $j$ and $z$ we have:

$$
L_{i, j}=L_{i, z}\left(\frac{N_{j}}{N_{z}}\right)^{\sigma \nu-(\nu+1)} \frac{Y_{w, j}}{Y_{w, z}}\left(\frac{Q_{j}}{Q_{z}}\right)^{\sigma}
$$

Integrating over the set $\Gamma$ of traded sectors in country $i$, we find:

$$
L_{i, j}=\kappa_{i, j} L_{i, \tau}
$$

where $\kappa_{i, j} \equiv \frac{\left(N_{j}\right)^{\sigma \nu-(\nu+1)} Y_{w, j}\left(Q_{j}\right)^{\sigma}}{\int_{\Gamma}\left(N_{z}\right)^{\sigma \nu-(\nu+1)} Y_{w, z}\left(Q_{z}\right)^{\sigma} d z}$ is a constant. Finally, with the expressions for $L_{i, j}$ at hand, we can substitute (27) and (28) into utility:

$$
C_{i}=\left[\exp \int_{0}^{1} \log Y_{i, j} d j\right]^{\eta_{i}} G_{i}^{1-\eta_{i}}=K_{i}\left[\left(1-g_{i}\right)^{1-\frac{\tau_{i}}{\sigma_{i}}}\right]^{\eta_{i}} g_{i}^{1-\eta_{i}}
$$

where $K_{i}$ collects all terms that are taken as given by country $i$. Maximizing $C_{i}$ with 
respect to $g_{i}$ gives:

$$
g_{i}=\frac{1-\eta_{i}}{1-\eta_{i} \tau_{i} / \sigma_{i}}
$$

which is a simple generalization of equation (15) in the text.

\subsection{Taxation and Optimal Trade Policy}

We now show that our results hold even when the government can set an optimal trade tax or, eqivalently, an import tariff. Consider, for example, an export tax whose revenue is redistributed to consumers, so that its only purpose is to maximize domestic income by improving the terms of trade as in the basic optimal tariff argument. For simplicity, we focus on the model with no uncertainty $(\epsilon=0)$. Let $p_{\tau}$ be the price of a traded variety inclusive of the export tax $t$. The after tax revenue from selling one unit, $p_{\tau}(1-t)$, is the wage of the worker who produced it:

$$
p_{\tau}(1-t)=w=p_{n}
$$

where $p_{n}$ is the price of a nontraded good. Thus, the effect of the export tax is to introduce a wedge between the price of exported and nontraded goods. Cobb-Douglas preferences and trade balance imply that income is evenly distributed across sectors: $p_{\tau} L_{\tau}=p_{n} L_{n}$, where $L_{\tau}$ and $L_{n}$ are employment in the typical traded and nontraded industry, respectively. Substituting (29) yields labor allocation in each sector: $L_{\tau}=(1-t) L_{n}$. As expected, the export tax shifts labor out of exporting industries and allows the government to choose employment levels in traded and nontraded sectors. With full employment, these are:

$$
\begin{aligned}
L_{\tau} & =\frac{(1-t)(1-g)}{1-t \tau} L, \\
L_{n} & =\frac{1-g}{1-t \tau} L .
\end{aligned}
$$

Substituting (30) for $(1-g) L$ into (11) and similarly (31) into (10), we get new expressions for $Y_{\tau}$ and $Y_{n}$ that in turn can be used with (12) to obtain the new objective function for the government:

$$
\underset{\{g, t\}}{\operatorname{Max}} U=\left(\frac{1-g}{1-t \tau}\right)^{(1-\tau) \eta}\left\{\left[\frac{(1-t)(1-g)}{1-t \tau}\right]^{\frac{\sigma-1}{\sigma}} N^{\nu-(\nu+1) / \sigma}\left(\frac{Y_{w}}{L}\right)^{\frac{1}{\sigma}}\right\}^{\tau \eta}(g L)^{1-\eta}
$$

Then, the first order condition for $t$ requires $t=\sigma^{-1}$, confirming the well-known result that the optimal export tax is the inverse of the foreign demand elasticity. More importantly, 
it is easy to verify from (32) that the first order condition for $g$ is still given by (15). The intuition for this result is as follows. Terms of trade considerations induce the government to restrict output of traded goods. The optimal tariff affects the allocation of labor between traded and non traded goods within the private sector, yet the government also wants to change the allocation between private and public (non traded) goods. The latter goal cannot be achieved with trade policy only. ${ }^{59}$

\subsection{INTERNATIONAL LABOR MOBILITY}

Following models of tax competition (see, for example, Gordon, 1983, or the survey in Persson and Tabellini, 1995), the effect of international labor mobility can be studied, albeit in a reduced form way, by assuming that the domestic labor force is elastic to taxation $g$. In particular, we define $\xi$ as the elasticity of $L$ to changes in taxation:

$$
\xi=-\frac{g}{L} \frac{\partial L}{\partial g}>0
$$

The idea is that some workers decide to migrate abroad as the tax rate increases, so that $\xi$ captures the degree of labor mobility. Although in a symmetric equilibrium workers will not move, the fact that governments are aware of the possible labor reaction is enough to affect their incentives. Maximization of (13) now yields a modified first order condition:

$$
\frac{\eta}{1-g}\left(1-\frac{\tau}{\sigma}\right)+(1-\eta) \frac{\xi}{g}=\frac{1-\eta}{g}+\frac{\tau \eta}{\sigma} \frac{\xi}{g}
$$

Note that $\xi$ increases both the cost (the left hand side) and the benefit (the right hand side) of taxation. On the cost side, the loss is due to the fact that $G$ is non-rival so that there are increasing returns in the provision of the public good. On the benefit side, a drop in $L$ leads to a positive terms of trade improvement. Solving for $g$ :

$$
g=\frac{1-\eta+\xi\left(\eta-1+\frac{\tau}{\sigma} \eta\right)}{1-\frac{\tau}{\sigma} \eta+\xi\left(\eta-1+\frac{\tau}{\sigma} \eta\right)}
$$

Note that, as long as $\tau<\sigma(1-\eta) / \eta$, an elastic labor supply lowers $g$, as in tax competition models, but it may reinforce the effect of $\tau$ :

$$
\frac{\partial g}{\partial \tau}=\frac{\eta[1-\eta+\xi(2 \eta-1)]}{\sigma\left[1-\frac{\tau}{\sigma} \eta+\xi\left(\eta-1+\frac{\tau}{\sigma} \eta\right)\right]^{2}} .
$$

\footnotetext{
${ }^{59}$ See also Boadway, Maital and Prachowny (1973) on the independence between optimal tariffs and domestic taxation.
} 
Sufficient conditions for $\frac{\partial g}{\partial \tau}$ to increase with $\xi$ are $\eta>0.5$ and $\xi<\frac{1-\frac{\tau}{\sigma} \eta}{1-\frac{\tau}{\sigma} \eta-\eta}>1$. Given that only a handful of countries have a government share higher than $50 \%$ of GDP and that international migration is still limited, these conditions do not seem very restrictive.

\subsection{Country Groups}

The countries with a relatively stronger association between openness and government size are: Albania, Angola, Antigua, Argentina, Australia, Bangladesh, Belarus, Belgium, Belize, Bolivia, Brazil, Burundi, Cameroon, Canada, Central African Republic, Chad, China, Comoros, Costa Rica, Cote d'Ivoire, Czech Republic, Denmark, Dominican Republic, Equatorial Guinea, Estonia, Ethiopia, Finland, France, Gambia, Germany, Greece, Guinea-Bissau, Guyana, Iceland, Iran, Israel, Italy, Jamaica, Japan, Jordan, Kyrgyzstan, Lesotho, Madagascar, Mali, Mozambique, Namibia, Nepal, Netherlands, New Zealand, Nigeria, Peru, Poland, Portugal, Romania, Russia, Sao Tome and Principe, Seychelles, Sierra Leone, Slovak Republic, Spain, Switzerland, Tanzania, Thailand, Togo, Turkey, Uganda, Ukraine, United Kingdom, Uruguay, USA, Uzbekistan, Venezuela, Vietnam.

The other countries are: Algeria, Armenia, Austria, Azerbaijan, Barbados, Benin, Botswana, Bulgaria, Burkina Faso, Cambodia, Cape Verde, Chile, Colombia, Congo, Congo, Dem. Rep., Cuba, Cyprus, Dominica, Ecuador, Egypt, El Salvador, Fiji, Gabon, Ghana, Grenada, Guatemala, Guinea, Haiti, Honduras, Hong Kong, Hungary, India, Indonesia, Ireland, Kazakhstan, Kenya, Latvia, Lebanon, Lithuania, Luxembourg, Macao, Macedonia, Malawi, Malaysia, Mauritania, Mauritius, Mexico, Morocco, Nicaragua, Niger, Norway, Pakistan, Panama, Papua New Guinea, Paraguay, Philippines, Republic of Korea, Rwanda, Senegal, Singapore, Slovenia, South Africa, Sri Lanka, St. Kitts \& Nevis, St. Lucia, St.Vincent \& Grenadines, Sweden, Syria, Taiwan, Trinidad \&Tobago, Tunisia, Yemen, Zambia, Zimbabwe. 
Table 1. Openness and Government Size (Cross-Sections)

Dependent variables: Government Consumption and Gov. Expenditure for Social Security and Welfare (\% of GDP)

\begin{tabular}{|c|c|c|c|c|c|c|c|c|c|c|c|}
\hline & $(1)$ & $(2)$ & (3) & (4) & (5) & (6) & $(7)$ & (8) & (9) & (10) & $(11)$ \\
\hline & \multicolumn{7}{|c|}{ Government Consumption } & \multicolumn{3}{|c|}{$\begin{array}{c}\text { Social Security and } \\
\text { Welfare }\end{array}$} & $\begin{array}{c}\text { Gov. Cons. } \\
\text { (same sample) }\end{array}$ \\
\hline \multirow[t]{2}{*}{ Openness } & $0.149 * * *$ & $0.138 * * *$ & $0.132^{\star * \star}$ & $0.104^{\star \star \star}$ & $0.167^{* * *}$ & $0.150^{* * \star}$ & $0.192^{\star * *}$ & 0.033 & -0.006 & 0.029 & $0.188^{* \star *}$ \\
\hline & {$[0.031]$} & {$[0.033]$} & [0.042] & {$[0.032]$} & {$[0.039]$} & {$[0.034]$} & [0.047] & {$[0.024]$} & {$[0.027]$} & [0.039] & {$[0.051]$} \\
\hline \multirow[t]{2}{*}{ Log of Income } & & $-4.346^{\star \star \star}$ & $-2.832^{\star \star \star}$ & $-6.055^{\star \star *}$ & $-6.271^{\star \star \star}$ & $-4.970 * \star \star$ & $-5.618^{\star * *}$ & & $4.052^{\star \star \star}$ & $2.568^{\star \star \star}$ & $-4.816^{\star \star}$ \\
\hline & & {$[0.759]$} & [0.953] & [1.180] & [1.125] & {$[1.300]$} & [1.317] & & {$[0.593]$} & {$[0.762]$} & [2.054] \\
\hline \multirow[t]{2}{*}{ Log of Population } & & -1.138 & -1.118 & $-1.767^{\star \star}$ & $-1.678^{\star \star}$ & 0.336 & 0.016 & & -0.597 & 0.551 & -0.871 \\
\hline & & [0.692] & [0.754] & [0.719] & [0.725] & [0.831] & [0.973] & & {$[0.536]$} & [0.654] & {$[0.796]$} \\
\hline \multirow[t]{2}{*}{ ToT Variability } & & & & & 6.771 & & $8.523^{\star}$ & & & 1.212 & $7.143^{*}$ \\
\hline & & & & & [4.397] & & [4.536] & & & [2.676] & [3.665] \\
\hline \multirow[t]{2}{*}{ Openness $\times$ ToT Var. } & & & & & $-0.149^{\star *}$ & & $-0.139 *$ & & & -0.040 & $-0.213^{*}$ \\
\hline & & & & & {$[0.071]$} & & [0.076] & & & {$[0.067]$} & [0.118] \\
\hline \multirow[t]{2}{*}{ Polity } & & & & & & -0.255 & -0.186 & & & & \\
\hline & & & & & & [0.293] & [0.268] & & & & \\
\hline \multirow[t]{2}{*}{ Black Market Premium } & & & & & & -0.000 & -0.000 & & & & \\
\hline & & & & & & [0.000] & {$[0.000]$} & & & & \\
\hline \multirow[t]{2}{*}{ Current Account Restr. } & & & & & & 2.592 & 1.856 & & & & \\
\hline & & & & & & [3.022] & [3.068] & & & & \\
\hline \multirow[t]{2}{*}{ Exchange Rate Restr. } & & & & & & -2.956 & -3.176 & & & & \\
\hline & & & & & & [2.838] & [2.974] & & & & \\
\hline \multirow[t]{2}{*}{ Capital Account Restr. } & & & & & & 1.556 & 1.584 & & & & \\
\hline & & & & & & [1.931] & [1.973] & & & & \\
\hline Regional Dummies & & & & YES & YES & YES & YES & & & YES & YES \\
\hline Observations & 143 & 143 & 115 & 143 & 131 & 111 & 104 & 58 & 58 & 55 & 55 \\
\hline R-squared & 0.20 & 0.38 & 0.30 & 0.54 & 0.55 & 0.60 & 0.60 & 0.03 & 0.41 & 0.76 & 0.61 \\
\hline
\end{tabular}

Cross-sectional OLS estimates with robust standard errors in brackets. ${ }^{* \star *},{ }^{* *},{ }^{*}=$ significant at the 1,5 and 10 percent levels, respectively. All variables are computed as period averages for the years 1995-2000, with the openness ratio lagged one five-year period. The dependent variable is government consumption in colums (1)-(7) and (11), and government expenditure for social security and welfare in columns (8)-(10). In column (3), all Western European countries are excluded from the sample. ToT Variability equals the standard deviation of terms of trade lagged one period. Polity equals polity2, the combined polity score drawn from the Polity IV dataset. Current Account, Capital Account and Exchange Rate Restrictions are dummy variables equal to one in the presence, respectively, of current account, capital account or exchange rate restrictions. Data sources: PWT 6.1, Polity IV, World Bank and IMF. 
Table 2. Openness, Export Differentiation and Government Size (Cross-Sections, I)

Dependent variable: Government Consumption (\% of GDP).

Export Differentiation Proxy $\left(z_{i}{ }^{r a}\right)$ built on Rauch (1999).

\begin{tabular}{|c|c|c|c|c|c|c|c|c|c|c|}
\hline & (1) & $\overline{(2)}$ & (3) & $\overline{(4)}$ & $\overline{(5)}$ & $\overline{(26)}$ & $\overline{(7)}$ & (8) & 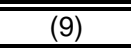 & $\overline{(10)}$ \\
\hline \multirow[t]{2}{*}{ Openness } & $0.150^{* * *}$ & 0.000 & 0.026 & -0.069 & 0.103 & -0.076 & 0.044 & 0.052 & -0.132 & 0.234 \\
\hline & {$[0.033]$} & {$[0.048]$} & [0.048] & {$[0.047]$} & [0.195] & [0.049] & {$[0.067]$} & [0.098] & [0.105] & [0.379] \\
\hline \multirow[t]{2}{*}{$z_{i}{ }^{r a}$} & -0.047 & $-0.241^{\star \star *}$ & $-0.125^{\star \star}$ & $-0.153^{\star \star}$ & $-0.178^{\star *}$ & $-0.188^{\star \star}$ & $-0.148^{\star \star}$ & $-0.142^{*}$ & -0.158 & $-0.155^{\star}$ \\
\hline & {$[0.034]$} & {$[0.066]$} & {$[0.062]$} & {$[0.073]$} & {$[0.074]$} & [0.082] & {$[0.071]$} & {$[0.073]$} & {$[0.098]$} & [0.092] \\
\hline \multirow{2}{*}{ Openness $\times z_{i}{ }^{l a}$} & & $0.279^{\star \star \star}$ & $0.229^{\star \star \star}$ & $0.317^{\star \star \star}$ & $0.349^{\star \star \star}$ & $0.349^{\star \star *}$ & $0.322^{\star \star \star}$ & $0.307^{\star \star \star}$ & $0.357^{\star \star *}$ & $0.356^{\star \star \star}$ \\
\hline & & [0.092] & [0.079] & [0.069] & {$[0.075]$} & [0.081] & {$[0.068]$} & {$[0.066]$} & [0.101] & [0.100] \\
\hline \multirow[t]{2}{*}{ Log of Income } & & & $-4.486^{\star \star \star}$ & $-6.782^{\star \star \star}$ & $-5.373^{\star \star \star}$ & $-7.747^{\star \star \star}$ & $-6.990^{\star \star \star}$ & $-6.806^{\star \star \star}$ & $-6.825^{\star \star \star}$ & $-6.404^{\star *}$ \\
\hline & & & [0.742] & [1.116] & [1.891] & [1.387] & [1.154] & [1.176] & [1.079] & [2.708] \\
\hline \multirow[t]{2}{*}{ Log of Population } & & & -0.491 & -0.735 & -0.815 & -0.570 & -0.824 & -0.816 & -0.554 & -0.366 \\
\hline & & & [0.791] & {$[0.717]$} & {$[0.725]$} & [0.713] & [0.695] & {$[0.714]$} & [0.696] & [0.695] \\
\hline \multirow[t]{2}{*}{ Openness $\times$ Log of Income } & & & & & -0.022 & & & & & -0.022 \\
\hline & & & & & [0.023] & & & & & [0.036] \\
\hline \multirow[t]{2}{*}{ Institutional Quality } & & & & & & 3.099 & & & & 2.207 \\
\hline & & & & & & [2.629] & & & & [3.548] \\
\hline \multirow[t]{2}{*}{ Openness $\times$ Institutional Quality } & & & & & & -0.017 & & & & 0.002 \\
\hline & & & & & & [0.030] & & & & [0.044] \\
\hline \multirow[t]{2}{*}{ ToT Variability } & & & & & & & $21.442^{\star \star}$ & & & \\
\hline & & & & & & & [10.095] & & & \\
\hline \multirow[t]{2}{*}{ Openness $\times$ ToT Variability } & & & & & & & $-0.294^{\star *}$ & & & \\
\hline & & & & & & & {$[0.147]$} & & & \\
\hline \multirow[t]{2}{*}{ St. Dev. $\Delta \log$ of ToT } & & & & & & & & 16.248 & & 18.508 \\
\hline & & & & & & & & [12.873] & & [12.948] \\
\hline Openness $\times$ St. Dev. $\Delta \log$ of ToT & & & & & & & & $\begin{array}{c}-0.250 \\
{[0.192]}\end{array}$ & & $\begin{array}{l}-0.280 \\
{[0.201]}\end{array}$ \\
\hline \multirow[t]{2}{*}{ Export Concentration } & & & & & & & & & -0.012 & 0.094 \\
\hline & & & & & & & & & [0.134] & [0.161] \\
\hline \multirow[t]{2}{*}{ Openness $\times$ Export Concentration } & & & & & & & & & 0.131 & -0.004 \\
\hline & & & & & & & & & [0.185] & [0.235] \\
\hline Regional Dummies & & & & YES & YES & YES & YES & YES & YES & YES \\
\hline Observations & 125 & 125 & 125 & 125 & 125 & 125 & 125 & 125 & 125 & 125 \\
\hline R-squared & 0.22 & 0.28 & 0.41 & 0.62 & 0.62 & 0.63 & 0.64 & 0.63 & 0.63 & 0.65 \\
\hline
\end{tabular}

See notes to Table 1. $z_{i}{ }^{\text {ra }}$ is computed as illustrated in the main text using Rauch (1999)'s classification. Institutional Quality is proxied by the Rule of Law index. St. Dev. $\Delta \log$ of ToT equals the standard deviation of the log change of terms of trade over the period 1960-2000. Export Concentration is the Herfindahl index of export concentration in the year 2000. Data sources: PWT 6.1, UN-Comtrade, Governance Matters IV, UNCTAD and Rauch (1999). 
Table 3. Openness, Export Differentiation and Government Size (Cross-Sections, II)

Dependent variable: Government Consumption (\% of GDP).

Export Differentiation Proxy $\left(z_{i}^{b w}\right)$ built on Broda and Weinstein (2006).

\begin{tabular}{|c|c|c|c|c|c|c|c|c|c|c|}
\hline & (1) & (2) & (3) & (4) & (5) & (6) & (7) & (8) & (9) & $(10)$ \\
\hline \multirow[t]{2}{*}{ Openness } & $0.146^{\star \star \star}$ & -0.044 & -0.023 & -0.064 & -0.073 & -0.074 & 0.026 & 0.071 & -0.076 & 0.280 \\
\hline & {$[0.033]$} & {$[0.087]$} & {$[0.080]$} & [0.079] & [0.328] & [0.083] & [0.086] & {$[0.120]$} & [0.145] & [0.469] \\
\hline \multirow[t]{2}{*}{$z_{i}^{b w}$} & -0.053 & $-0.469 * \star$ & $-0.352^{\star}$ & $-0.304^{\star}$ & -0.302 & $-0.369 *$ & $-0.325^{\star}$ & $-0.296^{*}$ & -0.294 & -0.334 \\
\hline & {$[0.105]$} & {$[0.218]$} & {$[0.197]$} & {$[0.177]$} & [0.205] & [0.199] & {$[0.176]$} & [0.164] & [0.215] & [0.207] \\
\hline \multirow[t]{2}{*}{ Openness $\times z_{i}{ }^{D w}$} & & $0.581^{\star \star}$ & $0.546^{\star \star}$ & $0.541^{\star *}$ & $0.538^{*}$ & $0.583^{\star *}$ & $0.568^{\star \star}$ & $0.544^{\star \star \star}$ & $0.557^{*}$ & $0.591^{\star \star}$ \\
\hline & & [0.253] & {$[0.245]$} & {$[0.230]$} & [0.288] & {$[0.260]$} & [0.232] & [0.205] & [0.302] & [0.292] \\
\hline \multirow[t]{2}{*}{ Log of Income } & & & $-4.310^{\star \star *}$ & $-6.572^{\star \star \star}$ & $-6.643^{\star *}$ & $-7.541^{\star * *}$ & $-6.700^{* * *}$ & $-6.565^{\star * *}$ & $-6.538^{* * *}$ & $-6.123^{*}$ \\
\hline & & & {$[0.805]$} & [1.191] & [2.693] & [1.492] & [1.210] & {$[1.254]$} & [1.208] & [3.443] \\
\hline \multirow[t]{2}{*}{ Log of Population } & & & -0.348 & -0.787 & -0.782 & -0.626 & -0.858 & -0.873 & -0.697 & -0.602 \\
\hline & & & {$[0.775]$} & {$[0.776]$} & [0.781] & [0.748] & [0.769] & {$[0.776]$} & [0.834] & [0.831] \\
\hline \multirow[t]{2}{*}{ Openness $\times$ Log of Income } & & & & & 0.001 & & & & & 0.559 \\
\hline & & & & & [0.042] & & & & & [3.863] \\
\hline \multirow[t]{2}{*}{ Institutional Quality } & & & & & & 1.615 & & & & 0.027 \\
\hline & & & & & & [2.911] & & & & [0.050] \\
\hline \multirow[t]{2}{*}{ Openness $\times$ Institutional Quality } & & & & & & 0.007 & & & & -0.021 \\
\hline & & & & & & [0.036] & & & & [0.050] \\
\hline \multirow[t]{2}{*}{ ToT Variability } & & & & & & & 18.859 & & & \\
\hline & & & & & & & [11.678] & & & \\
\hline \multirow[t]{2}{*}{ Openness $\times$ ToT Variability } & & & & & & & -0.247 & & & \\
\hline & & & & & & & [0.172] & & & \\
\hline \multirow[t]{2}{*}{ St. Dev. $\Delta \log$ of ToT } & & & & & & & & 18.189 & & 21.962 \\
\hline & & & & & & & & [13.371] & & {$[14.006]$} \\
\hline \multirow[t]{2}{*}{ Openness $\times$ St. Dev. $\Delta$ log of ToT } & & & & & & & & -0.295 & & -0.355 \\
\hline & & & & & & & & [0.198] & & [0.215] \\
\hline \multirow[t]{2}{*}{ Export Concentration } & & & & & & & & & 0.010 & 0.063 \\
\hline & & & & & & & & & [0.151] & [0.169] \\
\hline \multirow[t]{2}{*}{ Openness $\times$ Export Concentration } & & & & & & & & & 0.026 & -0.045 \\
\hline & & & & & & & & & [0.219] & {$[0.257]$} \\
\hline Regional Dummies & & & & YES & YES & YES & & YES & YES & YES \\
\hline Observations & 125 & 125 & 125 & 125 & 125 & 125 & 125 & 125 & 125 & 125 \\
\hline R-squared & 0.20 & 0.24 & 0.40 & 0.57 & 0.57 & 0.58 & 0.58 & 0.58 & 0.57 & 0.59 \\
\hline
\end{tabular}

See notes to previous tables. $z_{i}{ }^{b w}$ is computed as illustrated in the main text using Broda and Weinstein (2006)'s estimates. 
Table 4. Openness and Government Size (Fixed-Effects)

Dependent variables: Government Consumption and Gov. Expenditure for Social Security and Welfare (\% of GDP)

\begin{tabular}{|c|c|c|c|c|c|c|c|c|c|}
\hline & $(1)$ & $(2)$ & (3) & (4) & (5) & $(6)$ & $(7)$ & (8) & (9) \\
\hline & \multicolumn{5}{|c|}{ Government Consumption } & \multicolumn{3}{|c|}{ Social Security and Welfare } & $\begin{array}{c}\text { Gov cons. } \\
\text { (same sample) }\end{array}$ \\
\hline \multirow[t]{2}{*}{ Lagged Dependent Variable } & & $0.840^{* * \star}$ & & & & & $0.414^{\star \star \star}$ & & \\
\hline & & {$[0.041]$} & & & & & [0.100] & & \\
\hline \multirow[t]{2}{*}{ Openness } & $0.054^{\star \star *}$ & $0.039 * \star \star$ & $0.060^{\star \star \star}$ & $0.068^{\star \star \star}$ & $0.076^{\star \star \star}$ & -0.003 & $-0.022^{\star}$ & 0.000 & $0.117^{\star \star \star *}$ \\
\hline & {$[0.015]$} & {$[0.011]$} & {$[0.018]$} & {$[0.022]$} & {$[0.027]$} & [0.009] & [0.012] & [0.010] & [0.030] \\
\hline \multirow[t]{2}{*}{ Log of Income } & $-3.380^{\star \star \star}$ & -0.186 & $-3.173^{\star \star *}$ & 1.185 & 1.373 & $-1.632^{\star \star \star}$ & -0.484 & $-1.716^{\star \star \star}$ & 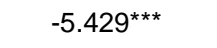 \\
\hline & [0.878] & {$[0.677]$} & [0.965] & [1.222] & [2.251] & [0.582] & [0.954] & [0.625] & [1.974] \\
\hline \multirow[t]{2}{*}{ Log of Population } & $7.047^{\star \star \star}$ & 1.098 & $6.851^{\star \star \star}$ & $7.723^{\star \star \star}$ & -14.711 & $-8.002^{\star \star \star}$ & -2.390 & $-8.065^{\star \star \star}$ & 5.108 \\
\hline & {$[1.651]$} & [1.460] & [1.792] & [2.400] & [11.663] & [0.989] & [2.105] & [1.030] & [3.253] \\
\hline \multirow[t]{2}{*}{ ToT Variability } & & & 0.617 & 0.769 & 1.313 & & & -0.369 & -0.264 \\
\hline & & & [1.292] & [1.411] & [1.192] & & & [0.475] & [1.500] \\
\hline \multirow[t]{2}{*}{ Openness $\times$ ToT Variability } & & & -0.022 & -0.026 & -0.031 & & & 0.008 & -0.003 \\
\hline & & & [0.019] & {$[0.024]$} & [0.020] & & & {$[0.007]$} & [0.022] \\
\hline \multirow[t]{2}{*}{ Polity } & & & & 0.043 & -0.049 & & & & \\
\hline & & & & [0.065] & [0.069] & & & & \\
\hline \multirow[t]{2}{*}{ Black Market Premium } & & & & $0.002^{\star \star \star}$ & $0.002^{\star \star \star}$ & & & & \\
\hline & & & & {$[0.000]$} & {$[0.000]$} & & & & \\
\hline \multirow[t]{2}{*}{ Current Account Restrictions } & & & & 0.636 & $2.147^{\star \star}$ & & & & \\
\hline & & & & [0.933] & [0.886] & & & & \\
\hline \multirow[t]{2}{*}{ Exchange Rate Restrictions } & & & & 0.038 & $-1.482^{*}$ & & & & \\
\hline & & & & [0.792] & {$[0.780]$} & & & & \\
\hline \multirow[t]{2}{*}{ Capital Account Restrictions } & & & & $2.058^{\star \star}$ & 1.413 & & & & \\
\hline & & & & [1.022] & [1.033] & & & & \\
\hline Country-Specific Trends & & & & & YES & & & & \\
\hline Time Dummies & YES & YES & YES & YES & YES & YES & YES & YES & YES \\
\hline Observations & 973 & 973 & 865 & 558 & 558 & 350 & 254 & 307 & 307 \\
\hline Countries & 128 & 128 & 127 & 94 & 94 & 78 & 68 & 76 & 76 \\
\hline R-squared & 0.23 & & 0.23 & 0.25 & 0.65 & 0.37 & & 0.40 & 0.22 \\
\hline
\end{tabular}


Table 5. Openness, Export Differentiation and Government Size (Fixed-Effects, I)

Dependent variable: Government Consumption (\% of GDP).

Export Differentiation Proxy $\left(z_{i}^{\text {ra }}\right)$ built on Rauch (1999).

\begin{tabular}{|c|c|c|c|c|c|c|c|c|}
\hline & $(1)$ & $(2)$ & $(3)$ & $(4)$ & (5) & $(6)$ & $(7)$ & $(8)$ \\
\hline \multirow[t]{2}{*}{ Openness } & $0.094^{\star \star \star}$ & 0.039 & -0.019 & 0.143 & -0.022 & -0.004 & $-0.222^{\star \star \star}$ & -0.152 \\
\hline & [0.014] & {$[0.026]$} & [0.023] & [0.090] & [0.023] & [0.026] & [0.043] & [0.122] \\
\hline \multirow[t]{2}{*}{ Openness $\times z_{i}{ }^{\prime a}$} & & $0.111^{* *}$ & $0.147^{\star \star \star}$ & $0.166^{\star \star \star}$ & $0.160 * \star \star$ & $0.135^{\star \star \star}$ & $0.280 * \star \star$ & $0.283^{\star \star \star}$ \\
\hline & & {$[0.047]$} & [0.043] & [0.044] & [0.044] & {$[0.046]$} & [0.048] & [0.052] \\
\hline \multirow[t]{2}{*}{ Log of Income } & & & $-2.820 * \star \star$ & -1.717 & $-2.911^{\star \star \star}$ & $-2.196^{\star \star}$ & $-2.378^{\star \star \star}$ & -1.278 \\
\hline & & & [0.903] & [1.080] & [0.907] & [0.964] & [0.889] & [1.201] \\
\hline \multirow[t]{2}{*}{ Log of Population } & & & $9.339 * \star \star$ & $8.678^{\star \star \star}$ & $8.613^{\star \star \star}$ & $9.313^{\star \star *}$ & $8.087^{\star \star \star}$ & $7.576^{\star \star \star}$ \\
\hline & & & [1.454] & [1.494] & [1.579] & [1.579] & [1.442] & [1.681] \\
\hline \multirow[t]{2}{*}{ Openness $\times$ Log of Income } & & & & $-0.020 *$ & & & & -0.009 \\
\hline & & & & [0.011] & & & & {$[0.013]$} \\
\hline \multirow[t]{2}{*}{ Openness × Institutional Quality } & & & & & -0.02 & & & -0.003 \\
\hline & & & & & {$[0.017]$} & & & {$[0.020]$} \\
\hline \multirow[t]{2}{*}{ ToT Variability } & & & & & & 0.289 & & 0.054 \\
\hline & & & & & & [1.184] & & [1.157] \\
\hline \multirow[t]{2}{*}{ Openness $\times$ ToT Variability } & & & & & & -0.014 & & -0.012 \\
\hline & & & & & & {$[0.017]$} & & {$[0.017]$} \\
\hline \multirow[t]{2}{*}{ Openness $\times$ Export Concentration } & & & & & & & $0.414^{\star \star \star}$ & $0.444^{\star \star \star}$ \\
\hline & & & & & & & {$[0.074]$} & {$[0.081]$} \\
\hline Time Dummies & & & YES & YES & YES & YES & YES & YES \\
\hline Observations & 973 & 859 & 859 & 859 & 859 & 765 & 859 & 765 \\
\hline Countries & 128 & 112 & 112 & 112 & 112 & 111 & 112 & 111 \\
\hline R-squared & 0.05 & 0.06 & 0.30 & 0.31 & 0.31 & 0.29 & 0.33 & 0.33 \\
\hline
\end{tabular}


Table 6. Openness, Export Differentiation and Government Size (Fixed-Effects, II)

Dependent variable: Government Consumption (\% of GDP).

Export Differentiation Proxy $\left(z_{i}{ }^{b w}\right)$ built on Broda and Weinstein (2006).

\begin{tabular}{|c|c|c|c|c|c|c|c|}
\hline & $(1)$ & $(2)$ & (3) & $(4)$ & $(5)$ & $(6)$ & $(7)$ \\
\hline \multirow[t]{2}{*}{ Openness } & -0.029 & $-0.092^{\star \star}$ & 0.095 & $-0.106^{\star \star \star}$ & $-0.076^{\star}$ & $-0.299^{\star \star \star}$ & -0.173 \\
\hline & [0.045] & [0.040] & {$[0.090]$} & [0.041] & [0.043] & {$[0.056]$} & [0.123] \\
\hline \multirow[t]{2}{*}{ Openness $\times z_{i}{ }^{b w}$} & $0.362^{\star \star *}$ & $0.421^{\star \star \star}$ & $0.509^{\star \star \star}$ & $0.473^{\star \star \star}$ & $0.413^{\star \star \star}$ & $0.669^{\star \star \star}$ & $0.750^{\star \star \star}$ \\
\hline & {$[0.130]$} & {$[0.115]$} & {$[0.121]$} & [0.120] & [0.128] & [0.123] & [0.140] \\
\hline \multirow[t]{2}{*}{ Log of Income } & & $-2.650^{\star \star \star}$ & -1.245 & $-2.758^{\star \star \star}$ & $-2.130^{\star \star}$ & $-2.039 \star \star$ & -0.629 \\
\hline & & [0.891] & {$[1.077]$} & [0.893] & [0.954] & [0.885] & [1.192] \\
\hline \multirow[t]{2}{*}{ Log of Population } & & $9.028^{\star \star \star}$ & $8.130^{\star * \star}$ & $8.066^{\star \star \star}$ & 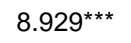 & 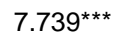 & $6.668^{\star \star \star}$ \\
\hline & & [1.452] & [1.499] & [1.590] & [1.576] & [1.451] & [1.705] \\
\hline \multirow[t]{2}{*}{ Openness $\times$ Log of Income } & & & $-0.026^{\star \star}$ & & & & -0.018 \\
\hline & & & {$[0.011]$} & & & & [0.013] \\
\hline Openness × Institutional Quality & & & & $\begin{array}{c}-0.026 \\
{[0.017]}\end{array}$ & & & $\begin{array}{c}-0.005 \\
{[0.020]}\end{array}$ \\
\hline ToT Variability & & & & & $\begin{array}{c}0.648 \\
{[1.184]}\end{array}$ & & $\begin{array}{c}0.737 \\
{[1.159]}\end{array}$ \\
\hline \multirow[t]{2}{*}{ Openness $\times$ ToT Variability } & & & & & -0.021 & & -0.024 \\
\hline & & & & & [0.017] & & [0.017] \\
\hline \multirow[t]{2}{*}{ Openness $\times$ Export Concentration } & & & & & & $0.356^{\star \star \star}$ & $0.382^{\star \star \star}$ \\
\hline & & & & & & {$[0.070]$} & {$[0.077]$} \\
\hline Time Dummies & & YES & YES & YES & YES & YES & YES \\
\hline Observations & 859 & 859 & 859 & 859 & 765 & 859 & 765 \\
\hline Countries & 112 & 112 & 112 & 112 & 111 & 112 & 111 \\
\hline R-squared & 0.06 & 0.31 & 0.31 & 0.31 & 0.29 & 0.33 & 0.33 \\
\hline
\end{tabular}


Table 7. IV and OLS Estimates of the Terms of Trade Externality

\begin{tabular}{|c|c|c|c|c|c|c|c|}
\hline & $(1)$ & (2) & (3) & (4) & (5) & (6) & (7) \\
\hline & GDP & GDP pc & rel GDP pc & GDP pc & GDP pc & GDP pc & rel GDP pc \\
\hline \multicolumn{8}{|c|}{ OLS regressions for the growth rate of non-fuel terms of trade } \\
\hline Growth of Private GDP & $\begin{array}{l}-0.322^{\star \star \star} \\
{[0.123]}\end{array}$ & $\begin{array}{c}-0.320^{\star * *} \\
{[0.104]}\end{array}$ & $\begin{array}{c}-0.327^{\star \star *} \\
{[0.113]}\end{array}$ & $\begin{array}{c}-0.263^{\star \star} \\
{[0.124]}\end{array}$ & $\begin{array}{c}-0.321^{\star \star \star} \\
{[0.101]}\end{array}$ & $\begin{array}{c}-0.288^{\star \star \star} \\
{[0.098]}\end{array}$ & $\begin{array}{c}-0.290^{\star \star} \\
{[0.111]}\end{array}$ \\
\hline Observations & 95 & 95 & 95 & 93 & 93 & 93 & 93 \\
\hline R-squared & 0.08 & 0.09 & 0.08 & 0.15 & 0.12 & 0.13 & 0.12 \\
\hline \multicolumn{8}{|c|}{ IV regressions for the growth rate of non-fuel terms of trade (Two-Stage Least Squares) } \\
\hline Growth of Private GDP & & & & $\begin{array}{c}-0.389^{*} \\
{[0.214]}\end{array}$ & $\begin{array}{c}-0.436^{\star \star \star} \\
{[0.136]}\end{array}$ & $\begin{array}{c}-0.427^{\star * *} \\
{[0.143]}\end{array}$ & $\begin{array}{c}-0.452^{\star \star \star} \\
{[0.154]}\end{array}$ \\
\hline Growth of Av. Years of Schooling & & & & & & $\begin{array}{c}0.099 \\
{[0.098]}\end{array}$ & $\begin{array}{c}0.060 \\
{[0.101]}\end{array}$ \\
\hline Growth of Gov. Share of GDP & & & & & & $\begin{array}{l}-0.031 \\
{[0.122]}\end{array}$ & $\begin{array}{c}-0.024 \\
{[0.125]}\end{array}$ \\
\hline Log of Av. Years of Schooling, 1960 & & & & $\begin{array}{l}-0.004 \\
{[0.003]}\end{array}$ & & & \\
\hline Log of Life Expectancy, 1962 & & & & $\begin{array}{c}0.000 \\
{[0.000]}\end{array}$ & & & \\
\hline R-squared & & & & 0.14 & 0.11 & 0.12 & 0.10 \\
\hline
\end{tabular}

First stage regressions for the growth rate of Private GDP

Log of Private GDP pc, 1960

$\begin{array}{cccc}-0.016^{\star \star \star} & -0.016^{\star \star \star} & -0.014^{\star \star \star} & -0.013^{\star \star \star} \\ {[0.003]} & {[0.003]} & {[0.002]} & {[0.002]} \\ 0.002 & 0.002 & 0.010^{\star \star} & 0.007^{\star} \\ {[0.002]} & {[0.002]} & {[0.004]} & {[0.004]} \\ 0.002^{\star \star \star} & 0.002^{\star \star \star} & 0.001^{\star \star \star} & 0.001^{\star \star \star} \\ {[0.000]} & {[0.000]} & {[0.000]} & {[0.000]} \\ & & 0.628^{\star \star \star} & 0.409^{\star *} \\ & & {[0.221]} & {[0.196]} \\ & & -0.297^{\star \star \star} & -0.272^{\star \star \star} \\ & & {[0.095]} & {[0.078]}\end{array}$

Log of Av. Years of Schooling, 1960

$\begin{array}{cccc}93 & 93 & 93 & 93 \\ 0.53 & 0.53 & 0.64 & 0.66\end{array}$

R-squared

F-statistic of Excluded Instruments

$36.1 \quad 33.6 \quad 32.1 \quad 36.1$

P-value J-stat. Overidentifying Restr.

$0.45 \quad 0.53 \quad 0.44$

Cross-sectional OLS and Instrumental Variables estimates. The growth rate of non-fuel terms of trade is computed as the annual growth rate of export prices minus the growth rate of import prices after netting out the change in fuel prices as in Backus and Crucini (2000). Private GDP is real GDP net of government consumption; it is measured as total GDP in column (1), in per capita terms in columns (2) and (4)-(6), and relative to trading partners in columns (3) and (7). Data sources: PWT 6.1, UN-Comtrade, Barro-Lee and World Bank. 
Table 8. The Terms of Trade Externality Across Groups

\begin{tabular}{rcccccccc}
\hline \hline & $(1)$ & $(2)$ & $(3)$ & $(4)$ & $(5)$ & $(6)$ & $(7)$ \\
\hline GDP & GDP pc & rel GDP pc & GDP pc & GDP pc & GDP pc & rel GDP pc \\
\hline
\end{tabular}

a) Countries with a stronger positive association between openness and government size

OLS regressions for the growth rate of non-fuel terms of trade

$\begin{array}{lcccccccc}\text { Growth of Private GDP } & -0.475^{\star *} & -0.571^{\star * *} & -0.583^{\star * *} & -0.488^{\star *} & -0.571^{\star * *} & -0.492^{\star *} & -0.518^{\star \star *} \\ \text { Observations } & {[0.214]} & {[0.169]} & {[0.165]} & {[0.228]} & {[0.169]} & {[0.195]} & {[0.193]} \\ \text { R-squared } & 47 & 47 & 47 & 47 & 47 & 47 & 47 \\ & 0.14 & 0.27 & 0.27 & 0.28 & 0.27 & 0.28 & 0.28\end{array}$

IV regressions for the growth rate of non-fuel terms of trade (Two-Stage Least Squares)

Growth of Private GDP

$\begin{array}{cccc}-0.670 & -0.673^{\star \star *} & -0.641^{\star *} & -0.651^{\star *} \\ {[0.500]} & {[0.214]} & {[0.281]} & {[0.284]} \\ & & 0.021 & -0.037 \\ & & {[0.143]} & {[0.150]} \\ & & 0.049 & 0.092 \\ & & {[0.179]} & {[0.172]} \\ 9.8 & 25.8 & 15.6 & 16.4 \\ & 0.85 & 0.50 & 0.74 \\ 0.27 & 0.26 & 0.27 & 0.27\end{array}$

\section{b) All other countries}

OLS regressions for the growth rate of non-fuel terms of trade

\begin{tabular}{|c|c|c|c|c|c|c|c|}
\hline Growth of Private GDP & $\begin{array}{l}-0.221 \\
{[0.169}\end{array}$ & $\begin{array}{l}-0.151 \\
{[0.129]}\end{array}$ & $\begin{array}{l}-0.128 \\
{[0.143]}\end{array}$ & $\begin{array}{l}-0.205 \\
{[0.182]}\end{array}$ & $\begin{array}{l}-0.151 \\
{[0.129]}\end{array}$ & $\begin{array}{c}-0.197 \\
{[0.125]}\end{array}$ & $\begin{array}{l}-0.190 \\
{[0.140]}\end{array}$ \\
\hline Observations & 48 & 48 & 48 & 46 & 46 & 46 & 46 \\
\hline R-squared & 0.03 & 0.02 & 0.01 & 0.03 & 0.02 & 0.05 & 0.04 \\
\hline \multicolumn{8}{|c|}{ IV regressions for the growth rate of non-fuel terms of trade (Two-Stage Least Squares) } \\
\hline \multirow[t]{2}{*}{ Growth of Private GDP } & & & & 0.112 & 0.062 & -0.088 & -0.082 \\
\hline & & & & {$[0.517]$} & [0.263] & [0.227] & [0.249] \\
\hline \multirow[t]{2}{*}{ Growth of Av. Years of Schooling } & & & & & & -0.250 & -0.255 \\
\hline & & & & & & {$[0.260]$} & [0.257] \\
\hline \multirow[t]{2}{*}{ Growth of Gov. Share of GDP } & & & & & & -0.055 & -0.052 \\
\hline & & & & & & [0.185] & [0.192] \\
\hline F-statistic of Excluded Instruments & & & & 13.0 & 9.8 & 14.1 & 14.0 \\
\hline P-value J-stat. Overidentifying Restr. & & & & & 0.99 & 0.39 & 0.40 \\
\hline R-squared & & & & 0.00 & 0.00 & 0.04 & 0.03 \\
\hline
\end{tabular}

See notes to Table 7 . 
Table A1. Home Bias in Government Consumption

\begin{tabular}{lcc}
\hline \hline & $\begin{array}{c}\text { Government Import } \\
\text { (\% of Gov. Consumption) }\end{array}$ & $\begin{array}{c}\text { Total Import } \\
\text { (\% of GDP) }\end{array}$ \\
\hline Brazil & 1.07 & 10.75 \\
Canada & 0.03 & 45.20 \\
Czech Republic & 1.78 & 64.17 \\
Denmark & 0.00 & 38.84 \\
Finland & 1.64 & 39.16 \\
Germany & 0.80 & 32.03 \\
Hungary & 1.67 & 53.94 \\
Indonesia & 3.38 & 30.56 \\
Ireland & 3.66 & 93.82 \\
Netherlands & 0.11 & 63.05 \\
Slovak Republic & 0.22 & 73.09 \\
Sweden & 0.02 & 48.13 \\
Switzerland & 0.04 & 44.70 \\
United Kingdom & 0.10 & 28.62 \\
Mean & 1.04 & 47.58 \\
\hline Datasoure: OECD Inpt-OuputTabs.
\end{tabular}

Data source: OECD Input-Output Tables. 
Table A2. Proxies for $1 / \sigma$ for the Countries in the Sample

\begin{tabular}{|c|c|c|c|c|c|}
\hline Country & $z_{i}{ }^{r a}$ & $z_{i}{ }^{b w}$ & Country & $z_{i}{ }^{r a}$ & $z_{i}^{b w}$ \\
\hline Albania & 76.97 & 33.30 & Jordan & 63.23 & 37.62 \\
\hline Algeria & 0.52 & 15.99 & Kazakhstan & 4.63 & 17.41 \\
\hline Antigua & 86.11 & 48.00 & Kenya & 22.40 & 28.17 \\
\hline Argentina & 27.11 & 22.18 & Korea & 73.38 & 37.94 \\
\hline Armenia & 19.81 & 39.75 & Kyrgyzstan & 17.07 & 42.23 \\
\hline Australia & 24.35 & 28.17 & Latvia & 64.31 & 27.52 \\
\hline Austria & 75.44 & 37.15 & Lebanon & 48.05 & 32.88 \\
\hline Azerbaijan & 4.47 & 10.16 & Lesotho & 98.10 & 26.67 \\
\hline Bangladesh & 89.01 & 36.38 & Lithuania & 51.41 & 25.66 \\
\hline Barbados & 41.76 & 26.53 & Macao & 91.52 & 38.04 \\
\hline Belarus & 61.39 & 28.27 & Macedonia & 48.60 & 28.02 \\
\hline Belgium & 58.05 & 38.25 & Madagascar & 57.86 & 37.11 \\
\hline Belize & 16.22 & 25.10 & Malawi & 8.68 & 22.31 \\
\hline Benin & 6.37 & 12.06 & Mali & 4.31 & 46.13 \\
\hline Bolivia & 18.37 & 28.92 & Mauritius & 76.99 & 32.98 \\
\hline Botswana & 7.43 & 55.83 & Mexico & 76.70 & 35.62 \\
\hline Brazil & 46.90 & 23.91 & Morocco & 56.69 & 35.17 \\
\hline Bulgaria & 55.06 & 28.87 & Mozambique & 8.50 & 28.23 \\
\hline Burkina Faso & 13.99 & 11.14 & Namibia & 29.46 & 42.90 \\
\hline Burundi & 7.58 & 20.75 & Nepal & 87.67 & 34.86 \\
\hline Cambodia & 94.74 & 37.86 & Netherlands & 61.83 & 31.19 \\
\hline Cameroon & 15.93 & 14.86 & New Zealand & 32.10 & 26.27 \\
\hline Canada & 65.23 & 31.93 & Nicaragua & 10.12 & 28.77 \\
\hline Cape Verde & 92.55 & 23.77 & Niger & 27.57 & 20.37 \\
\hline Central African Rep. & 12.38 & 49.24 & Nigeria & 0.17 & 5.95 \\
\hline Chile & 17.17 & 25.94 & Norway & 21.65 & 15.65 \\
\hline China & 79.86 & 40.49 & Pakistan & 60.96 & 36.62 \\
\hline Colombia & 31.61 & 23.60 & Panama & 23.61 & 25.83 \\
\hline Comoros & 11.25 & 22.90 & Papua New Guinea & 2.66 & 25.46 \\
\hline Costa Rica & 50.22 & 36.22 & Paraguay & 17.91 & 22.03 \\
\hline Cote d'Ivoire & 18.82 & 25.65 & Peru & 16.23 & 37.04 \\
\hline Cuba & 4.67 & 9.90 & Philippines & 89.83 & 33.83 \\
\hline Cyprus & 36.43 & 28.02 & Poland & 72.15 & 32.88 \\
\hline Czech Republic & 74.52 & 38.90 & Portugal & 77.44 & 37.40 \\
\hline Denmark & 67.16 & 32.37 & Romania & 71.84 & 31.42 \\
\hline Dominica & 59.96 & 35.00 & Russia & 33.70 & 16.79 \\
\hline Ecuador & 11.69 & 19.34 & Senegal & 17.63 & 28.42 \\
\hline Egypt & 31.30 & 19.91 & Slovak Republic & 71.12 & 37.76 \\
\hline El Salvador & 41.38 & 29.73 & Slovenia & 76.50 & 39.34 \\
\hline Estonia & 70.38 & 32.76 & South Africa & 55.89 & 28.08 \\
\hline Ethiopia & 27.43 & 25.92 & Spain & 70.29 & 38.25 \\
\hline Fiji & 56.62 & 26.22 & St. Kitts \& Nevis & 73.30 & 38.15 \\
\hline Finland & 61.54 & 36.82 & St. Lucia & 22.83 & 19.17 \\
\hline France & 70.67 & 36.60 & Sweden & 74.56 & 38.45 \\
\hline Gabon & 1.62 & 8.99 & Switzerland & 73.59 & 40.42 \\
\hline Gambia & 23.21 & 46.57 & Syria & 23.05 & 18.40 \\
\hline Germany & 78.92 & 37.46 & Tanzania & 10.43 & 40.53 \\
\hline Ghana & 12.53 & 47.36 & Thailand & 64.92 & 37.74 \\
\hline Greece & 46.98 & 29.90 & Togo & 21.80 & 24.57 \\
\hline Grenada & 60.71 & 42.45 & Trinidad \&Tobago & 7.33 & 18.20 \\
\hline Guatemala & 29.91 & 25.88 & Tunisia & 69.57 & 30.53 \\
\hline Guinea & 15.02 & 42.87 & Turkey & 68.83 & 35.15 \\
\hline Honduras & 17.63 & 30.61 & USA & 75.23 & 36.98 \\
\hline Hungary & 81.37 & 34.44 & Uganda & 8.81 & 26.44 \\
\hline Iceland & 19.78 & 27.49 & Ukraine & 26.71 & 24.94 \\
\hline India & 50.11 & 40.68 & United Kingdom & 71.46 & 38.08 \\
\hline Indonesia & 40.91 & 30.89 & Uruguay & 39.51 & 26.75 \\
\hline Iran & 6.17 & 9.88 & Venezuela & 3.22 & 12.18 \\
\hline Ireland & 64.16 & 35.37 & Vietnam & 43.55 & 25.55 \\
\hline Israel & 52.28 & 51.69 & Yemen & 1.04 & 8.04 \\
\hline Italy & 80.51 & 35.97 & Zambia & 21.84 & 24.87 \\
\hline Jamaica & 17.75 & 34.72 & Zimbabwe & 22.24 & 24.49 \\
\hline Japan & 85.40 & 43.40 & Mean & 42.80 & 30.22 \\
\hline
\end{tabular}

